\title{
A new suprageneric classification of the Proteaceae, with an annotated checklist of genera
}

\author{
Peter H. Weston ${ }^{1}$ and Nigel P. Barker ${ }^{2}$ \\ ${ }^{1}$ National Herbarium of New South Wales, Botanic Gardens Trust, Mrs Macquaries Road, Sydney \\ NSW 2000, Australia \\ ${ }^{2}$ Department of Botany, Rhodes University, Grahamstown 6140, South Africa
}

\begin{abstract}
A new suprageneric classification of the Proteaceae is presented that takes account of available molecular systematic results, synthesised as a phylogenetic supertree. Subfamilial, tribal and subtribal names are recircumscribed or created, where necessary, to ensure the putative monophyly of named higher taxa. Subfamilies, tribes and subtribes are briefly described. One new subfamily, Symphionematoideae, two new tribes, Petrophileae, Leucadendreae, and four new subtribes, Leucadendreae subtribe Isopogoninae, Leucadendreae subtribe Leucadendrinae, Macadamieae subtribe Malagasiinae and Macadamieae subtribe Virotiinae are named. Information is provided on the number of species currently recognised in, and distribution of, each genus, and the most recent generic taxonomic treatments are cited. Challenges to the monophyly of some genera are briefly discussed.
\end{abstract}

\section{Introduction}

The most recent, complete suprageneric classification of the Proteaceae was published over thirty years ago, as part of a highly influential monograph on the evolution and biogeography of the family (Johnson \& Briggs 1975). The phylogenetic analysis that this classification reflected was based primarily on morphological, anatomical and cytological characters, as well as a few micromolecular attributes (such as the ability to accumulate aluminium in the leaves) and biotic associations (pollinators). Johnson and Briggs described their analytical procedure as 'admittedly less "repeatable" or formally "objective" than 'cladistic taximetric approaches' but 'no less likely to represent the truth' (Johnson \& Briggs 1975: 98). Their philosophical approach to classification is more accurately described as 'gradistic' than 'cladistic': 'grades, when sufficiently well characterised and presumably monophyletic, are recognised as taxa, and the practical impossibility as well as the theoretical difficulties of pure cladism are acknowledged' (Johnson \& Briggs 1975: 88). 
Johnson and Briggs' classification was amended slightly by Douglas (1995) in response to the discovery of a new genus, Eidothea, and the recognition that no morphological evidence supported the inclusion of Bellendena in the subfamily Persoonioideae. Nevertheless, Johnson and Briggs' classification has served as the systematic framework for a generation of researchers working on the comparative biology of the Proteaceae, including those interested in taxonomy (e.g. Rourke 1984a), phylogeny reconstruction (e.g. Midgley 1987), morphology (e.g. Douglas 1996), historical biogeography (e.g. Weston \& Crisp 1996), anatomy (e.g. Catling \& Gates 1995), cytology (e.g. Wiltshire \& Stace 1997), palynology (e.g. Feuer 1990), paleobotany (e.g. Hill et al. 1995), reproductive biology (e.g. Collins \& Rebelo 1987) and ecology (e.g. Cowling \& Lamont 1998). However, much has changed since 1975 in the way that phylogenies are reconstructed and in the way they are used to justify higher level classifications. DNA sequences are now used routinely as a source of characters for phylogenetic analysis and explicit algorithms are routinely used to analyse them. Although a few systematists continue to advocate a gradistic or phenetic approach to classification (see e.g. Brummitt 1996) we agree with Hennig (1966), Nelson and Platnick (1981) and many others, who argue that cladistic classification is preferable. In making taxonomic changes to maximise the number of named higher taxa for which there exists good evidence of monophyly, we agree with Backlund and Bremer (1998) and Entwisle and Weston (2005) that nomenclatural stability should be a primary criterion in the choice of appropriate ranks for putative clades.

In recent years, several phylogenetic analyses of members of the Proteaceae have been conducted using DNA sequence data and algorithmic phylogenetic methods. Some of these analyses have been published while others are still in preparation. Hoot and Douglas (1998) is an analysis of representatives of most genera of Proteaceae, based on an alignment of DNA sequences for the chloroplast loci atp $\beta$ and the atp $\beta-r b c \mathrm{~L}$ intergenic spacer. Mast and Givnish (2002: fig. 2) is an analysis of 28 species of Banksia plus five species of Dryandra and representatives of 12 outgroup genera, based on an alignment of cpDNA sequences for the rpl16 intron, trnL intron and trnL-trnF intergenic spacer. Barker et al. (2002) is an analysis of representatives of 19 genera of the subfamily Proteoideae, with particular emphasis given to African taxa, based on an alignment of ITS1-5.8S-ITS2 nrDNA sequences. Analyses of a sample of most genera of Proteaceae, based on ITS1-5.8S-ITS2 nrDNA and rbcL cpDNA sequences, by P.H. Weston, N.P. Barker and K. Downs (hereafter cited as WB\&D ITS and WB\&D $r b c L$, respectively) are still being prepared for publication. These analyses are largely congruent with one another in corroborating the monophyly of some of Johnson and Briggs' suprageneric taxa but also indicate that others are probably not monophyletic.

Only a small fraction of the species of Proteaceae have been sampled in the molecular systematic studies mentioned above, so it is fair to say that classification of the family is still based primarily on morphology, at least at the generic level. Although monophyly of a number of genera has been minimally tested using molecular data, only Banksia has been subject to detailed sampling at the species level (Mast 1998, Mast \& Givnish 2002) and was shown to be non-monophyletic by inclusion of Dryandra, the genus that was previously thought to be its sister group (Thiele \& Ladiges 1996). Barker et al. (2002) also showed that several of the African genera (Mimetes, Sorocephalus, Spatalla and Paranomus) could potentially be non-monophyletic, but with less comprehensive sampling of species. The main advances that molecular analyses have made resolve clades at the ranks of subtribe, tribe and subfamily in Johnson and Briggs' classification. 
Although we expect further taxonomic changes at generic and higher levels in the Proteaceae, it is timely to update its classification by recircumscribing subfamilies, tribes and subtribes where molecular analyses strongly indicate that change is required.

One of us (PHW) has prepared a treatment of the Proteaceae for 'Families and Genera of Vascular Plants', and a supra-generic classification is required as part of this treatment. The primary purpose of this paper is to formalise the names of several clades that had not been named previously. In order to present these new names in a meaningful context, we have synthesised the results of molecular systematic analyses using supertree analysis (see e.g. Bininda-Emonds et al. 2002, 2004) to provide as complete a suprageneric classification as phylogenetic knowledge available to us allows. Presenting this classification required a complete listing of currently recognised genera, so we also took the opportunity to present some additional information on each genus that users are likely to find helpful: the number of species presently recognised; a verbal description of the geographic distribution; references to general taxonomic treatments (revisions and/or regional flora accounts) and more recently named species; plus comments on any challenges to the accepted taxonomic circumscription of the genus.

\section{Methods}

A supertree analysis using matrix representation and parsimony ('MRP' - BinindaEmonds et al. 2002, 2004) was conducted that synthesised the results of published and unpublished molecular phylogenetic analyses of the Proteaceae (Hoot \& Douglas 1998, Mast \& Givnish 2002, Barker et al. 2002 (Analysis 1), WB\&D ITS and WB\&D rbcL - see above). The terminal taxa were currently recognised genera of Proteaceae. Each character was a component (sensu Nelson \& Platnick 1981) of a bootstrap majority rule consensus tree for one of the molecular phylogenies. A total of 136 components were coded as characters in the data matrix. The states for each character were the membership (1) or non-membership (0) of a genus in the relevant component.

Generic membership of several components of the bootstrap consensus tree of Hoot and Douglas (1998) was modified to exclude dubiously or wrongly identified samples. The genera Protea, Roupala and Floydia were excluded from the coding of their tree for the following reasons. Hoot and Douglas (1998) reported Leucadendron to be more closely related to Protea than to either Adenanthos or Isopogon, contrary to our results (Barker et al. 2002, WB\&D rbcL). We checked the identity of their DNA sequences of Protea neriifolia by examining a digital image of their voucher specimen and it is definitely a specimen of Leucadendron, although we could not identify it to species. The DNA sequences that Hoot and Douglas (1998: 317) reported for Roupala and Floydia were identical. This result is incredible, given that these genera are morphologically quite dissimilar and occur on different continents. We strongly suspect that one or other sequence was obtained from misidentified material. We requested a loan of the relevant voucher specimens from MEL, but these could not be found, so we took the cautious approach of excluding both taxa from our coding of Hoot and Douglas' tree.

Each character was weighted according to the bootstrap value of its component as shown in Table 1. Note that the relationship between these weights and bootstrap support is curvilinear, in recognition of the fact that the bootstrap index is a ratio and does not vary linearly with the number of uncontradicted synapomorphies supporting a group. It is easy to estimate the expected bootstrap percentages equivalent to various 
Table 1: Character weighting scheme used in supertree analysis. The boundaries, in bootstrap percentages, delimiting the lower and upper bounds of each integral character weight, correspond to equivalent numbers of uncontradicted synapomorphies $(1=64.1 \%, 2=88.3 \%, 3$ $=96.4 \%, 4=99.0 \%, 5=99.4 \%)$.

Range of bootstrap values of component

$<64.1 \%$

$64.1-88.3 \%$

$88.4-96.4 \%$

$96.5-99.0 \%$

$99.1-100 \%$

\section{Character weight}

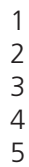

numbers of uncontradicted synapomorphies by constructing an artificial, ideal data set consisting of absolutely congruent "characters". We made such a matrix and subjected it to a bootstrap analysis with 100,000 replicates, conducted using the branch and bound search option of PAUP ${ }^{\star}$ version $4.0 \mathrm{~b} 10$. The following equivalences were shown by this exercise: one uncontradicted synapomorphy is equivalent to a bootstrap percentage of $64.1 \%$, two to $88.3 \%$, three to $96.4 \%$, four to $99.0 \%$, and five to $99.4 \%$. The boundaries, in bootstrap percentages, delimiting the lower and upper bounds of each of our integral character weights were based on these equivalences.

An all-zero outgroup was included to root the tree. The character matrix was subjected to parsimony analysis in PAUP* version $4.0 \mathrm{~b} 10$ using default settings (heuristic search with TBR branch-swapping). Equally parsimonious trees were summarised as a strict consensus tree. An undesirable property of the MRP method is that some of the groupings that it produces may not be represented in any of the input trees (see e.g. Bininda-Emonds 2003, Goloboff 2005). We inspected the groupings on our consensus tree to identify those that were not components of any of the molecular phylogenies that our supertree was meant to synthesise.

\section{Results}

186630 equally parsimonious trees were found, the strict consensus of which is shown in Fig. 1. Of 59 components that constitute this tree, only one, the cluster of Eucarpha with Floydia and Darlingia, is not found in any of the input trees. This appears to be the spurious result of interactions between lowly weighted components of the ITS and $r b c \mathrm{~L}$ input trees. This grouping was eliminated from consideration as a potential named taxon. This supertree was used as the basis for our suprageneric classification described below. Bootstrap support indices for the components of our supertree, from the original phylogenetic analyses, are shown in Table 2.

Fig. 1. MRP supertree of genera of Proteaceae, produced by taking the strict consensus of 186630 equally parsimonious trees resulting from an analysis of weighted components from available molecular phylogenies for the Proteaceae (see Methods and Results sections for details). Numbered rectangles on the right hand side of the figure refer to named higher taxa recognised here, signified by their numbers in the taxonomic treatment (subfamilies by digits $1-5$ in the left-hand column, tribes by numbers $2.1-5.4$ in the middle column and subtribes by numbers 4.1.1-5.4.4 in the right-hand column of rectangles). 


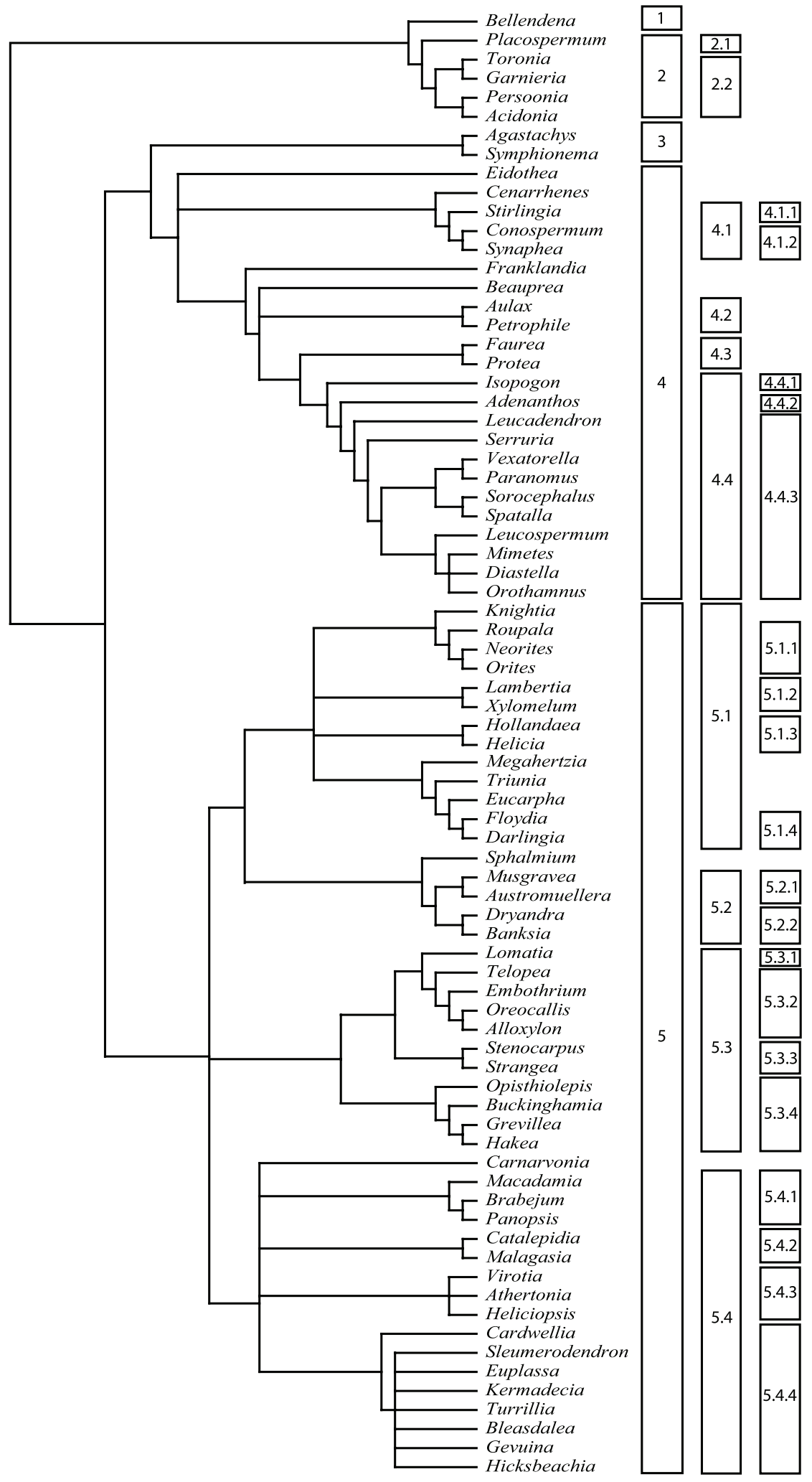




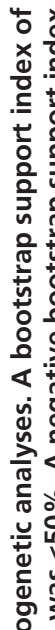

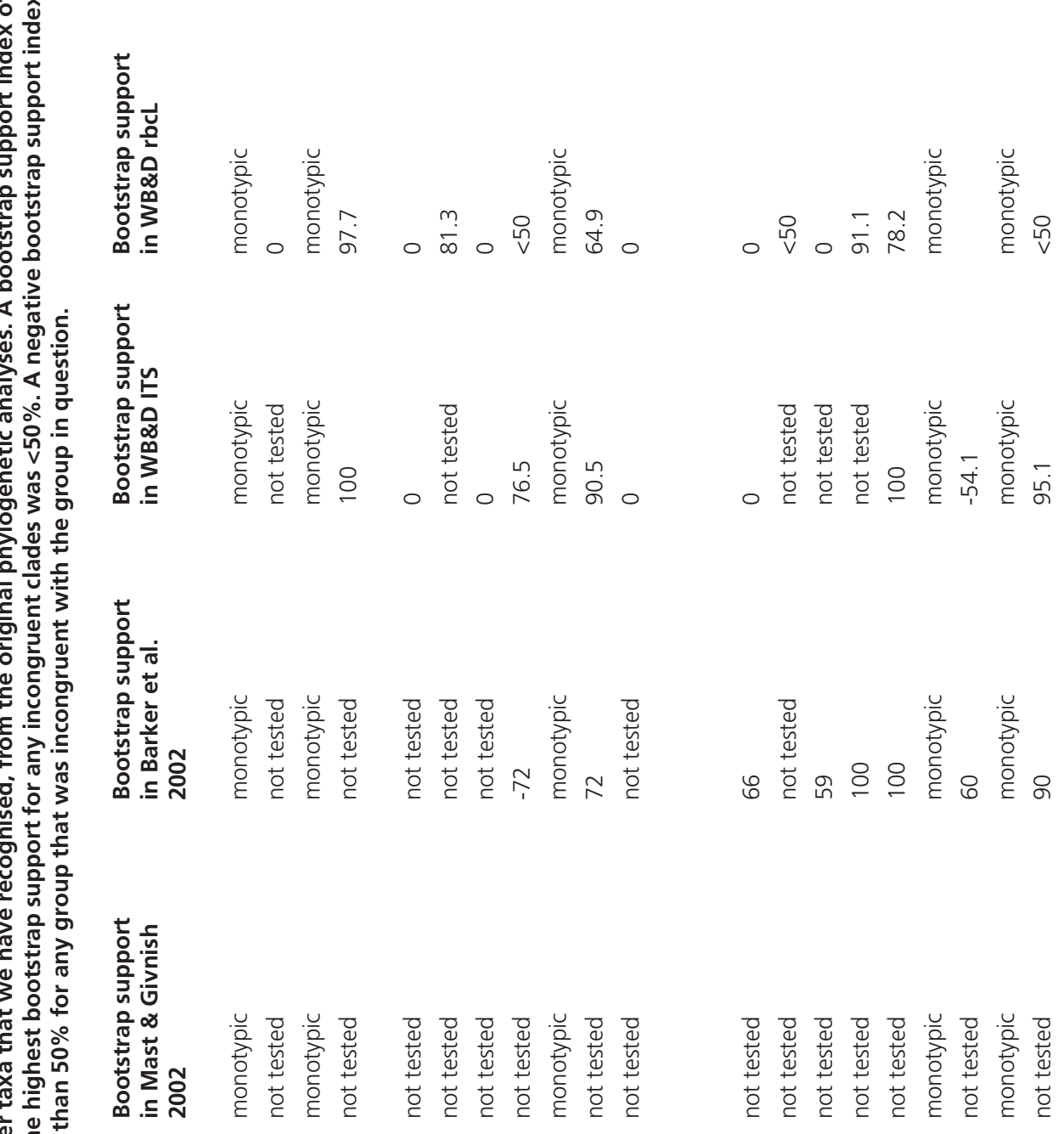

政

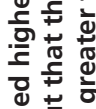

垔言

$\frac{n}{\frac{\pi}{0}}$

글 웅

政

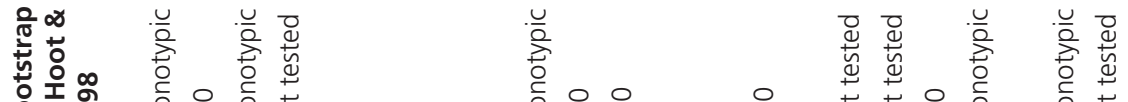

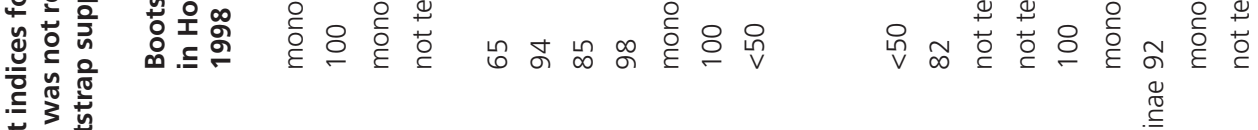

능 응

윽은

워욛

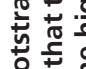

웜

范

은 흥 흥

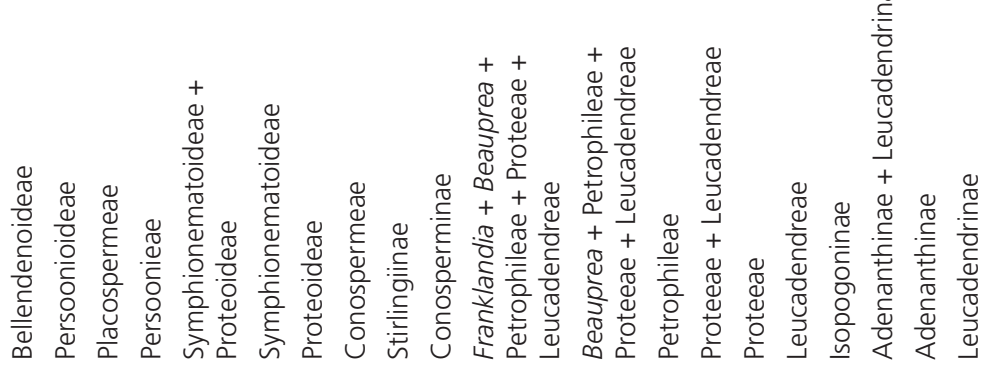




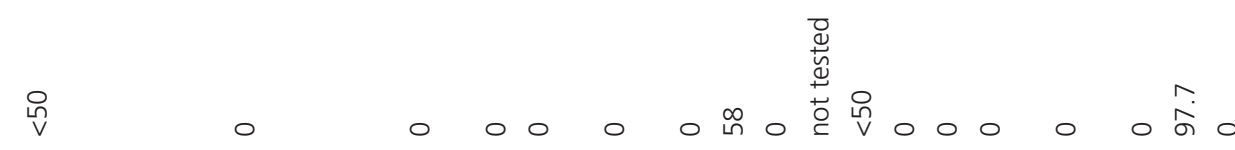

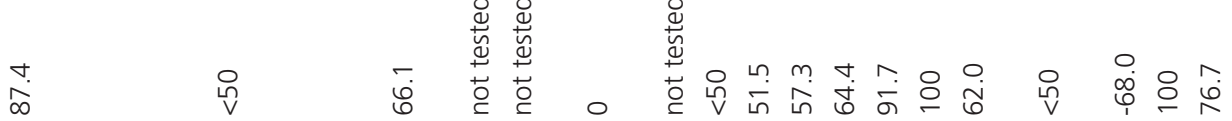

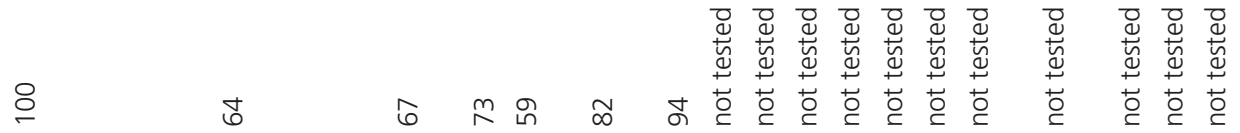

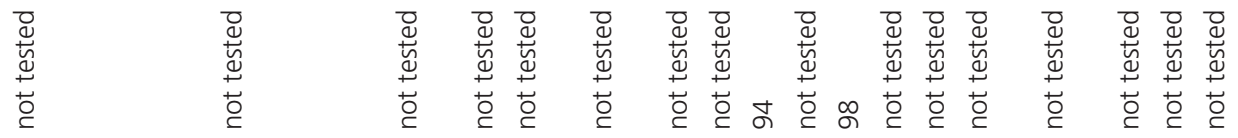

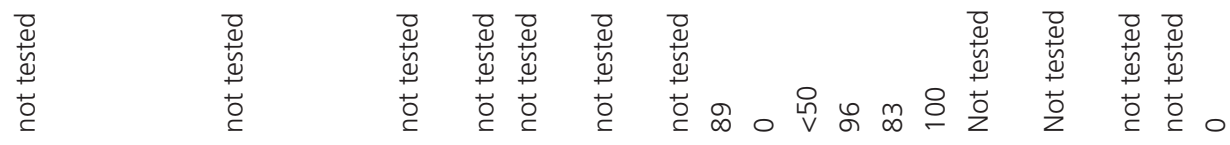

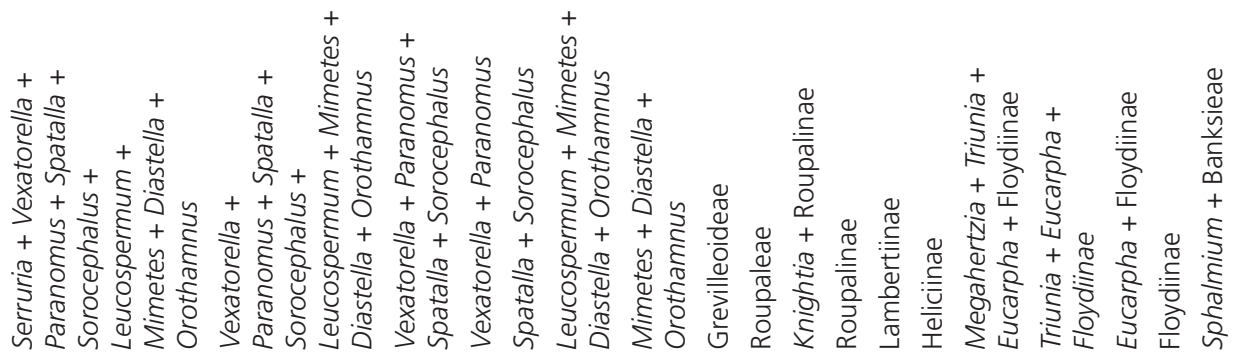


营

旁

फ्र

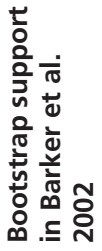

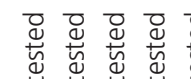

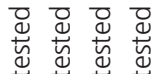

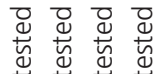

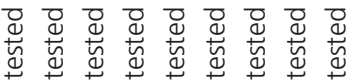

苍苍苍苍苍苍苍苍苍

듣 믇

苍

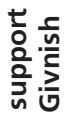

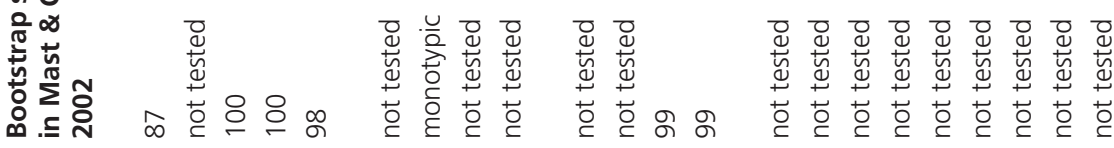

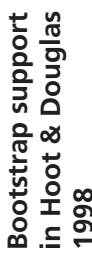

$\frac{0}{\frac{0}{2}}$

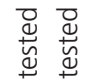

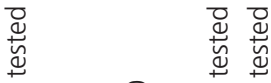

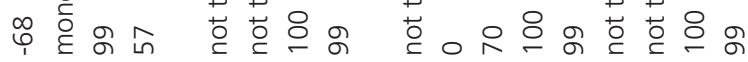

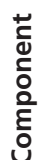

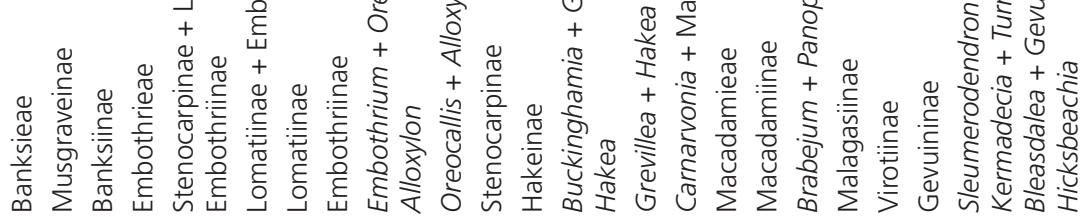


Subfamilies, tribes and subtribes. Only two of the seven subfamilies recognised in Douglas' (1995) slightly modified version of Johnson and Briggs' (1975) classification, subfamilies Bellendenoideae and Persoonioideae, are monophyletic, according to our supertree. Moreover, one of these, the Bellendenoideae, is monospecific and thus monophyletic by definition. However, a set of five, putatively monophyletic subfamilies can be formed with only minor changes to the circumscriptions of existing named taxa.

In chloroplast DNA analyses, Bellendena is either resolved as sister group to the rest of the family ("the rest" receiving 61\% bootstrap support, Hoot \& Douglas 1998), or left in an unresolved, basal position (WB\&D $r b c \mathrm{~L}$ ). Our ITS analysis (WB\&D ITS) was rooted at its midpoint, which resulted in Bellendena being resolved as sister group to the Persoonioideae in Fig. 1. An anatomical character that supports the position of Bellendena as sister group to the rest of the Proteaceae is its possession of laterocytic stomata, in common with Platanus and unlike all other Proteaceae, which have brachyparacytic stomata (Carpenter et al. 2005). Putative autapomorphies of the Bellendenoideae include the mostly ebracteate flowers, winged fruit and chromosome number of $\mathrm{n}=5$ (Johnson \& Briggs 1975).

The monophyly of subfamily Persoonioideae, is either strongly supported (Hoot \& Douglas 1998) or weakly contradicted (WB\&D rbcL) by molecular analyses (Table 2). The unusually large chromosomes are probably a synapomorphy for the subfamily (Johnson \& Briggs 1975, Weston 1994, Stace et al. 1998). The sister group relationship of the Persoonioideae to the rest of the Proteaceae is either moderately supported in molecular analyses ("the rest" receiving $81 \%$ bootstrap support in Hoot \& Douglas 1998 ) or weakly contradicted by them (WB\&D rbcL).

One of the two tribes of Persoonioideae recognised by Douglas (1995), the Placospermeae, is monospecific and thus monophyletic by definition. Its putative autapomorphies include andromonoecy, and sterilisation of anterior and lateral stamens. Follicular fruits, containing numerous transversely oriented seeds, are also likely to be autapomorphic given that the fruits of Nelumbo, Platanus, Symphionematoideae, Proteoideae and Persoonieae are indehiscent. The other tribe, Persoonieae, is monophyletic in our supertree and was strongly supported in the two analyses in which it has been tested (WB\&D ITS, WB\&D rbcL, see Table 2). The drupaceous fruit, in which the endocarp develops from proliferation of the inner epidermis of the carpel (Johnson \& Briggs 1975, Stroeschen 1986), is likely to be a synapomorphy for this tribe (Weston 1994).

Douglas' monogeneric subfamily Eidotheoideae is nested within the subfamily Proteoideae sensu Douglas according to Fig. 1 and sinking the former into the latter would render the Proteoideae monophyletic and so we have done this. However, we have also chosen to recognise the clade of Symphionema and Agastachys, which is sister group of the rest of the Proteoideae, as a new subfamily, the Symphionematoideae, for several reasons. Firstly, the monophyly of the Symphionematoideae was corroborated in both of the analyses in which it was tested. Secondly, the monophyly of the more narrowly circumscribed Proteoideae is more strongly supported than that of Proteoideae sensu lato (Table 2). Thirdly, excluding Symphionematoideae from the Proteoideae allows the straightforward morphological diagnosis of both of these subfamilies from Persoonioideae. Symphionematoideae differs from Persoonioideae in having dry indehiscent fruits, while Proteoideae s.s. differs from Persoonioideae in possessing cluster roots (in all taxa examined). 
Our subfamily Symphionematoideae is diagnosed by a combination of the following character states: absence of cluster roots (Lee 1978) and possession of dry, indehiscent fruits. Given the presence of cluster roots in Bellendena, their absence in Symphionematoideae is likely to represent secondary loss. Loss of cluster roots is therefore a putative synapomorphy for this subfamily, albeit one paralleled in subfamily Persoonioideae.

Subfamily Proteoideae as circumscribed here is diagnosed by a combination of the following character states: presence of cluster roots, ovule solitary (with rare, biovulate flowers in some species of Isopogon and Petrophile) and possession of indehiscent fruits. Reduction in ovule number from two to one could be a synapomorphy for the Proteoideae, but with parallels in Persoonioideae (some species of Persoonia), Symphionematoideae (Agastachys) and Grevilleoideae (some species of Strangea).

Neither Dilobeia nor Beaupreopsis have been sampled in any molecular phylogenetic analyses of the Proteaceae, nor have they been screened for presence of cluster roots. Their membership in subfamily Proteoideae is thus highly provisional. Their drupaceous fruits suggest a possible relationship with Eidothea, Cenarrhenes and Beauprea and although these genera do not form a clade in any of the molecular analyses, their possible monophyly is not strongly contradicted either.

We have recognised four tribes in the subfamily Proteoideae: Conospermeae, Petrophileae, Proteeae and Leucadendreae. The tribe Conospermeae, as broadly circumscribed by Johnson and Briggs (1975) and Douglas (1995), is strongly contradicted by all of the molecular analyses in which it has been tested and appears to be polyphyletic. However, a more narrowly circumscribed Conospermeae, as recognised here, and earlier as an unnamed group by Johnson and Briggs (1963), was supported in three of the four analyses in which it has been tested (Hoot \& Douglas 1998, WB\&D ITS, WB\&D $r b c L$ ). The analysis in which it was found to be paraphyletic (Barker et al. 2002) included only two non-Proteoid outgroups and this result is likely to be a sampling artifact. Coherence of fertile anther loculi to the fertile loculi of adjacent anthers is a putative synapomorpy supporting this clade.

Within the Conospermeae, Conospermum and Synaphea are resolved as sister groups in every analysis in which the three genera have been represented (Hoot \& Douglas 1998, WB\&D ITS, WB\&D rbcL). The grouping of the latter two genera was formally recognised by Johnson and Briggs (1975) as subtribe Conosperminae and they placed Stirlingia in a monogeneric subtribe Stirlingiinae. Those authors noted that Conospermum and Synaphea "show perianth zygomorphy, partial sterilisation of the androecium and unusual pollination mechanisms, but these must be of independent origin in view of the opposite direction of the zygomorphy in the two genera. Nevertheless they share a common reduced chromosome number of $n=11$, true gamotepaly and suppression of the intersporangial septum in each anther lobe" (Johnson \& Briggs 1975: 104). Apart from the zygomorphic features, all of these character states are putative synapomorphies for the Conosperminae.

The tribe Petrophileae is resolved as monophyletic in both published (Hoot \& Douglas 1998) and unpublished (WB\&D rbcL) analyses in which both genera have been represented. However, Petrophile and Aulax share no obvious morphological synapomorphies nor even a simple diagnostic combination of morphological character states. Moreover, Petrophile is superficially very similar to Isopogon, with which it has previously been grouped (Johnson \& Briggs 1963, 1975; Venkata Rao 1971; 
Douglas 1995). Nevertheless, the Petrophileae do possess at least one putative, nonmacromolecular synapomorphy, the shared synthesis of pinitol, a polyol sugar, which is found elsewhere in the Proteaceae only in Persoonioideae tribe Persoonieae (Bieleski \& Briggs 2005). Petrophile plus Aulax are a putative clade for which a formal name would be useful, especially given their biogeographically significant, disjunct distribution spanning the Indian Ocean, so we have recognised this group as a new tribe.

The monophyly of the tribe Proteeae, as broadly circumscribed by Johnson and Briggs (1975) and Douglas (1995), is strongly refuted by all of the molecular analyses in which it has been tested (Hoot \& Douglas 1998, Barker et al. 2002, WB\&D ITS, WB\&D rbcL). However, a much more narrowly circumscribed Proteeae, including only Protea and Faurea, as recognised here, and earlier as an unnamed grouping by Johnson and Briggs (1963, 1975), is strongly supported as monophyletic (Barker et al. 2002, WB\&D ITS, $\mathrm{WB} \& \mathrm{D} r b c \mathrm{~L}$ ). These genera share a form of floral zygomorphy in which the perianth splits into two lobes, the anterior tepal being free or basally connate to the others and the 3 posterior tepals being completely connate or almost so. This feature is a putative synapomorphy for the Proteeae, albeit with a parallel, similar synapomorphy in Leucospermum. Other putative non-macromolecular synapomorphies include the shared production of high concentrations of polygalatol, a polyol sugar (Bieleski \& Briggs 2005) and shared production of xylose-rich nectar (Nicolson \& van Wyk 1998).

The tribe Leucadendreae is newly named here to signify a clade that includes most of the South African genera of Proteaceae, together with the Australian genera Adenanthos and Isopogon. This clade is moderately to strongly supported in all of the molecular analyses in which it has been tested (Hoot \& Douglas 1998, Barker et al. 2002, WB\&D ITS, WB\&D rbcL, Table 2) but possesses no obvious morphological synapomorphies. It is a large, morphologically diverse group that is difficult to diagnose. Nevertheless, a formal name will be useful for this clade because of its biogeographic significance.

Within tribe Leucadendreae, the Australian genus Adenanthos is resolved as sister group to a large clade of southern African genera that have been informally dubbed the "Cape Clade" (Barker et al. 2002) and, together, they are the sister group of Isopogon. Here we formally name the "Cape Clade" as subtribe Leucadendrinae. This group is characterised by no morphological synapmorphies but can be diagnosed from other taxa by a combination of symplesiomorphous character states. Adenanthos was placed in its own monogeneric subtribe by Johnson and Briggs (1975) and we recognise it in our classification, together with a new monogeneric subtribe Isopogoninae. We acknowledge that such monotypic subtribes have no information content and can thus be regarded as taxonomically redundant. However, they have traditionally been used in botanical nomenclature as an alternative to listing genera as incertae sedis and it is this tradition that we follow here.

Johnson and Briggs (1975) recognised two monospecific subfamilies, the Sphalmioideae and Carnarvonioideae, which are nested within the subfamily Grevilleoideae according to our supertree. Sinking the former two taxa into the Grevilleoideae renders the latter a well supported monophyletic subfamily, so we have done this.

The monophyly of Grevilleoideae sensu lato is supported by the shared possession of auriculate cotyledons by the great majority of taxa that have been sampled for this character, including Sphalmium and Carnarvonia. Cotyledon auricles are apparently connate (i.e. the cotyledons are peltate) in Panopsis cinnamomea and are obscure in 
Hollandaea and Cardwellia, apparently due to thickening and widening, respectively, of the cotyledons in these taxa. All other subfamilies of Proteaceae, as well as Platanus, have non-auriculate cotyledons, so auricles seem likely to be a synapomorphy for the Grevilleoideae. Follicular fruits may also be a synapomorphy for the Grevilleoideae, contrary to the suggestion of Johnson and Briggs (1975) that follicles are plesiomorphous within the Proteaceae. Our interpretation relies on three hypotheses of homology. Firstly the dry, indehiscent fruits of Symphionematoidae and most Proteoideae must be homologous with the very similar ones of the outgroup Platanus but non-homologous with the very dissimilar indehiscent fruits of some Grevilleoideae. Secondly, the follicles of Placospermum must be non-homologous with the quite dissimilar ones of the Grevilleoideae. Thirdly, the indehiscent fruits of some Grevilleoideae must be modified follicles, an argument put in some detail and with great force by Johnson and Briggs (1975: 133-138).

We have recognised four tribes in the subfamily Grevilleoidae, all of which are resolved in some molecular analyses but only one of which, the Banksieae, is strongly supported in all analyses in which it has been tested (Hoot \& Douglas 1998, Mast \& Givnish 2002, WB\&D ITS, WB\&D $r b c \mathrm{~L}$ ). We have recognised these groups at tribal rank in part to maintain nomenclatural stability of a number of better supported subtribes already recognised by Johnson and Briggs (1975) and Douglas (1995) and in the expectation that phylogenetic research currently in progress (by Austin Mast and co-workers) will resolve clades at the tribal level with greater confidence in the near future.

The tribe Roupaleae is an assemblage that is difficult to diagnose morphologically from the Macadamieae. It is largely composed of genera that were previously included in Johnson and Briggs' (1975) tribes Oriteae, Knightieae and Helicieae. Most of these genera have actinomorphic perianths (but in Triunia and most species of Lambertia they are zygomorphic), hemitropous to anatropous ovules (but in Roupala, Floydia and Lambertia they are orthotropous), follicular fruits (but in Triunia, Helicia and Floydia they are indehiscent) and flattened, winged seeds (but in Triunia, Helicia and Floydia they are globose and wingless). While monophyly of Johnson and Briggs' Oriteae is not strongly rejected in any molecular analyses, their tribes Knightieae and Helicieae are both strongly shown to be polyphyletic. It would not be surprising if future discoveries also demonstrated our Roupaleae to be polyphyletic, thus necessitating further taxonomic change at tribal level. However, our Roupaleae is better supported than alternative tribal circumscriptions in this part of the family, given available evidence.

The name Roupaleae, which was published by Meisner (1841) as "Rhopaleae", has nomenclatural priority over the other tribal names that are available for this group. The name was ignored by late twentieth century taxonomists (e.g. Johnson and Briggs 1963, 1975; Venkata Rao 1971, Douglas 1995), presumably because they thought it was illegitimate. Meisner listed the previously published tribal name Grevilleeae as a synonym of his "Rhopaleae", thus rendering his name superfluous when published.

We are confident of the identity of the Roupala sequences that were included in two analyses (Mast \& Givnish 2002, WB\&D ITS) and in both of these Roupala was weakly to strongly grouped with Orites and Neorites (Table 2). These three genera constitute our subtribe Roupalinae. They share no putative morphological synapomorphies but are similar enough to have been a source of some confusion at the generic level (Prance et al. in press). The name Roupalinae was published by Johnson and Briggs (1975) to refer to their grouping of Roupala and Kermadecia, two quite distantly related genera according to our unpublished ITS analysis (WB\&D ITS). 
The name Lambertiinae was created by Johnson and Briggs (1975) as a monogeneric subtribe within the tribe Macadamieae. However, all analyses that have included samples of both Lambertia and Xylomelum (Hoot \& Douglas 1998, WB\&D ITS, WB\&D $r b c \mathrm{~L}$ ) have clustered them as sister taxa with moderate to strong support (Table 2), outside the Macadamieae. Consequently, we have placed them together in the subtribe Lambertiinae. The only putative morphological synapomorphy that they share is opposite to whorled foliar phyllotaxis, a character state that has evolved repeatedly in several different lineages of Proteaceae.

The subtribe Heliciinae was named by Johnson and Briggs (1975) to group Helicia with Xylomelum. However, this grouping is strongly contradicted in all three analyses in which both genera have been sampled and is highly likely to be polyphyletic. Instead, Helicia is strongly clustered with Hollandaea in two of the three analyses in which both the genera were sampled (Hoot \& Douglas 1998, WB\&D ITS, Table 2) a result that is neither supported nor contradicted by the third analysis (WB\&D $r b c \mathrm{~L}$ ). Consequently, we have used this available subtribal name for the Helicia-Hollandaea clade. Helicia and Hollandaea have similar, rather non-descript vegetative and floral morphology but have dramatically different fruits. However, they share fleshy, wingless seeds and anatropous ovules, both of which are probably synapomorphies for the subtribe, albeit homoplasious ones.

The subtribe Floydiinae was published by Johnson and Briggs (1975) as a monogeneric subtribe in their tribe Macadamieae. This tribal placement seemed to make sense morphologically because Floydia shares two orthotropous ovules, and an indehiscent fruit containing a globose, wingless seed with many members of that tribe. However, the two molecular analyses in which we were confident of the identity of the Floydia DNA sequences (WB\&D ITS, WB\&D $r b c \mathrm{~L}$ ) both strongly grouped this genus with the two species of Darlingia (Table 2), a member of Johnson and Briggs' (1975) Knightieae. Although these genera differ spectacularly in their ovule, fruit and seed morphology (Darlingia has four hemitropous ovules, follicular fruits and flat, winged seeds), their flowers are very similar, albeit lacking any shared, novel character states.

Members of the tribe Macadamieae are superficially similar to some members of the Roupaleae but are almost uniformly characterised by having two, orthotropous ovules, and indehiscent or very tardily dehiscent fruits, each containing a solitary, globose to ellipsoidal, unwinged seed. The only genus that lacks these character states, the monospecific Cardwellia, has numerous hemitropous ovules, and massive follicular fruits, each containing numerous, flat, prominently winged seeds. Despite these morphological differences, membership of Cardwellia in the tribe Macadamieae is weakly to strongly supported in all of the molecular analyses in which it has been sampled (Hoot \& Douglas 1998, WB\&D ITS, WB\&D rbcL). Our circumscription of Macadamieae is similar to that of Johnson and Briggs (1975), but differs in excluding Floydia, Roupala and Lambertia (to Roupaleae) and including Cardwellia (from Johnson and Briggs' tribe Knightieae).

In our supertree (Fig. 1), the genus Carnarvonia was included within the Macadamieae as part of a basal polytomy, the other lineages of which we have recognised as subtribes. Despite this result, we decided not to include Carnarvonia as a monotypic subtribe in our circumscription of Macadamieae because, for several reasons, we have little confidence in the veracity of this placement. Firstly, only one of the three analyses in which Carnarvonia was represented (WB\&D ITS) resolved this genus as 
belonging to the Macadamieae, with less than 50\% bootstrap support, as sister group to the subtribe Gevuininae. Secondly, Carnarvonia was placed in its own subfamily by Johnson and Briggs on the grounds that it lacked what they regarded as the most distinctive synapomorphy of their subfamily Grevilleoideae, inflorescences with grevilleoid flower pairs. Douglas (1996), in a detailed study of inflorescence and flower development in Carnarvonia, confirms the complete absence of even a vestige of the development of flower pairs in Carnarvonia. These observations are more consistent with a basal position of Carnarvonia within the Grevilleoideae than membership of the Macadamieae. Thirdly, Carnarvonia lacks the morphological character states that are typical of most other members of the Macadamieae: orthotropous ovules, fleshy cotyledons, unwinged seeds and indehiscent or tardily dehiscent fruits. We have thus chosen to retain Carnarvonia in the subfamily Grevilleoideae as a genus incertae sedis.

Monophyly of the subtribe Gevuininae, as newly circumscribed here, is strongly supported in two of the three molecular analyses in which it has been tested (Hoot \& Douglas 1998, WB\&D ITS, Table 2) and was neither supported nor contradicted by the third (WB\&D $r b c \mathrm{~L}$ ). To the three genera included by Johnson and Briggs (1975) in their more narrowly defined Gevuininae are added Bleasdalea and Turrillia (not formally recognised when Johnson and Briggs submitted their paper for publication but both implicitly included in Gevuina by them), Cardwellia (from their polyphyletic tribe Knightieae), Hicksbeachia (from their polyphyletic Macadamieae: Hicksbeachiinae) and Kermadecia (from their polyphyletic Macadamieae: Roupalinae). All taxa of Gevuininae for which floral development has been investigated in detail (Cardwellia sublimis, Sleumerodendron austrocaledonicum, Gevuina avellana, Bleasdalea bleasdalei) are characterised by carpels oriented so that the ventral suture faces the abaxial tepal (Douglas \& Tucker 1996). The only other species in which this condition has been observed is Xylomelum salicinum (Roupaleae: Lambertiinae). Moreover, most members of the Gevuininae share a novel form of floral zygomorphy in which the style is abaxially hooked through $180^{\circ}$ and the adaxial tepal is straight, in contrast to the other three, recurved tepals. These morphological features are likely to form a syndrome of synapomorphies for the Gevuininae.

The subtribe Macadamiinae as circumscribed by Johnson and Briggs (1975) and Douglas (1995) is strongly corroborated as monophyletic in two of the three molecular analyses in which it has been tested (Hoot \& Douglas 1998, WB\&D ITS, Table 2). This result is neither supported nor contradicted by our unpublished $r b c \mathrm{~L}$ analysis (WB\&D $r b c \mathrm{~L}$ ) in which its three genera form part of a large polytomy. In all three genera the nectary forms a cup or collar-like structure surrounding the ovary, a condition that seems most likely to have resulted from connation of four free hypogynous glands. A similar condition is found elsewhere in the Macadamieae only in Virotia, in which it seems likely to have evolved convergently. Johnson and Briggs (1975: 110) add that the group is characterised by 'a strong tendency to opposite or whorled phyllotaxy, lacking only in some species of Panopsis', a feature that is likely to be synapomorphous for the subtribe, given its absence in other taxa of Macadamieae.

The subtribe Virotiinae, newly recognised here, is moderately to strongly supported as monophyletic in the two molecular analyses in which it has been tested (WB\&D ITS, WB\&D $r b c \mathrm{~L}$ ). Its three genera, Virotia, Athertonia and Heliciopsis, all share a distinctive reticulate to foveate surface sculpturing of the woody inner mesocarp of the drupe-like fruits. This contrasts with the smooth surface sculpturing of the inner mesocarp in other members of the Grevilleoideae with drupe-like fruits. 
The subtribe Malagasiinae, also newly recognised here, is moderately to strongly supported as monophyletic in the two molecular analyses in which it has been tested (WB\&D ITS, WB\&D rbcL). Its two genera, Malagasia and Catalepidia, do not share any distinctive morphological characters states but nor do either of them share any such states with other genera.

The tribe Banksieae, as circumscribed by Johnson and Briggs (1975) and Douglas (1995) is weakly to moderately corroborated as monophyletic in three of the four molecular analyses in which it has been tested (Hoot \& Douglas 1998, Mast \& Givnish 2002, Barker et al. 2002, WB\&D ITS). The only analysis in which its monophyly was unsupported was our unpublished analysis of $r b c \mathrm{~L}$ sequences (WB\&D $r b c \mathrm{~L}$ ), where the two subtribes formed part of a large polytomy. Putative morphological synapomorphies for the tribe include biporate pollen grains (otherwise found in the Proteaceae only in Embothrium coccineum and in atypical grains of a few other species, see e.g. Dettmann \& Jarzen 1998), the presence of trichomes with unusually long, thin terminal cells, and 'banksioid' leaf venation (Johnson \& Briggs 1975, Thiele \& Ladiges 1996).

The two subtribes of the Banksieae, which were first recognised at this rank by Johnson and Briggs (1975), are moderately to strongly supported as monophyletic in all of the molecular analyses in which they have been tested (Table 2). The subtribe Banksiinae is characterised by four morphological and anatomical synapomorphies according to Thiele and Ladiges (1996): follicles with a bony endocarp, the presence of an interseminal false dissepiment, presence of vascular tissue in the wood rays, and a condensed conflorescence axis. The subtribe Musgraveinae is characterised by reduction in the number of hypogynous nectary glands from four to three (Johnson \& Briggs 1975), a putative synapomorphy that is paralleled in Lomatia. Another novel morphological character state shared by Musgravea and Austromuellera is the antrorseappressed cotyledons of their seedlings (Hyland 1999, Sankowsky et al. 1988).

Our tribe Embothrieae results from combining two of Johnson and Briggs' (1975) tribes: their Embothrieae and Grevilleeae. Molecular phylogenetic analyses consistently show that a paraphyletic doublet of two genera of Johnson and Briggs' Embothrieae, Buckinghamia and Opisthiolepis, are most closely related to their Grevilleeae. Molecular analyses have been less consistent in corroborating the monophyly of our Embothrieae as a whole, with only two out of four analyses in which this tribe was tested weakly to moderately supporting it (Mast \& Givnish 2002, WB\&D ITS, Table 2). However, the dissenting analyses (Hoot \& Douglas 1998, WB\&D rbcL) neither support nor contradict its monophyly. Although this group possesses no obvious morphological synapomorphies the chromosome numbers found in these taxa, $n=11$ and $n=10$ were interpreted as synapomorphic by both Johnson and Briggs (1975) and Stace et al. (1998), relative to the $n=12-15$ found in other Grevilleoideae.

Our tribe Embothrieae contains four subtribes, three of which are circumscribed as by Johnson and Briggs (1975). The monogeneric subtribe Lomatiinae was grouped by Johnson and Briggs with the Embothriinae in an unnamed putative clade, a position that is consistent with our supertree but which is contradicted by one of the molecular analyses. Hoot and Douglas (1998) found Lomatia to cluster with Stenocarpus with 68\% bootstrap support, so retaining Lomatia in its own subtribe rather than sinking it into the Embothriinae maintains nomenclatural stability at the same time as acknowledging conflicting information concerning its closest relatives. 
The subtribe Embothriinae was strongly supported as monophyletic in two of the three molecular analyses in which it was tested (Hoot \& Douglas 1998, WB\&D ITS, Table 2). This result was weakly contradicted by our unpublished $r b c \mathrm{~L}$ analysis (WB\&D $r b c \mathrm{~L}$ ) in which Alloxylon was grouped with other members of the Embothrieae, with less than $50 \%$ bootstrap support. The four genera of Embothriinae share several morphological synapomorphies (Johnson \& Briggs 1975, Weston \& Crisp 1994), all of which are paralleled in other grevilleoid lineages.

The subtribe Stenocarpinae consists of Stenocarpus and Strangea, two genera that Johnson and Briggs (1975) grouped together on the basis of the novel, envelopelike morphology of their outer seed wing. To that putative synapomorphy can be added the umbel-like inflorescence shared by all species of Stenocarpus and Strangea stenocarpoides, the only species of Strangea in which the inflorescence has not been reduced to one or two flowers.

The subtribe Hakeinae, newly recognised here, combines Johnson and Briggs' (1975) Embothrieae subtribe Buckinghamiinae with their tribe Grevilleeae. The genus Finschia, which has not been sampled yet in any molecular analysis, is closely related to Grevillea and Hakea on the basis of shared, apomorphous, morphological and cytological character states (Johnson \& Briggs 1975) such as diagonally oriented zygomorphic flowers, biramous trichomes, reduction in ovule number to two and reduction in chromosome number to $n=10$. All of these states are convergently derived in other lineages of Proteaceae but Finschia seems most unlikely to be more closely related to any other genera. Monophyly of the Hakeinae is weakly to strongly corroborated in all four of the molecular analyses in which it has been tested.

\section{Taxonomy}

Family Proteaceae Juss.

(Jussieu 1789: 78)

\section{Subfamily Bellendenoideae P.H.Weston}

(Weston 1995b: 472)

Cluster roots present. Cotyledons not auriculate. Inflorescence a mostly ebracteate raceme. Staminal filaments free. Hypogynous glands absent. Ovules 2. Fruit dry, indehiscent, 2-winged. Chromosomes $\mathrm{n}=5$, mean length $6.7 \mu \mathrm{m}$.

\section{Bellendena R.Br.}

One sp. (B. montana R.Br.), Tasmania (Weston 1995b).

2. Subfamily Persoonioideae L.A.S.Johnson \& B.G.Briggs

(Johnson \& Briggs 1975: 170)

Cluster roots absent. Cotyledons not auriculate. Inflorescence a bracteate raceme or spike or panicle of racemes. Staminal filaments largely or completely adnate to tepals; anthers free or basally (or completely) adnate to tepals. Hypogynous glands present. Fruit not winged. Chromosomes $\mathrm{n}=7$ or rarely $\mathrm{n}=14$; mean length $9.1-14.4 \mu \mathrm{m}$.

\subsection{Tribe Placospermeae C.T.White \& W.D.Francis}

(White \& Francis 1924: 79)

Andromonoecious trees. Cotyledons obreniform, shortly stalked, flat. Leaves entire in the seedling phase, deeply lobed in the juvenile phase, entire in the adult phase. 
Inflorescence a raceme or more commonly a panicle of racemes. Stamens dimorphic; posterior stamen fertile, prominently apiculate; anteriors and lateral stamens sterile. Ovary sessile; ovules 15-22. Fruit follicular; endocarp leathery, not penetrating between the seeds. Seeds 15-22, flat, transversely oriented, bilaterally winged.

2. Placospermum C.T.White \& W.D.Francis

One sp. (P. coriaceum C.T.White \& W.D.Francis), NE Australia (Weston 1995a: 4749).

\subsection{Tribe Persoonieae Rchb.}

(Reichenbach 1828: 81)

Bisexual trees or shrubs. Cotyledons elliptic to linear, sessile, semicircular to semiellipsoidal to triangular in cross-section. Leaves entire. Inflorescence a raceme or spike (often leafy and auxotelic in Persoonia). Stamens monomorphic (abaxial anther sterile and adnate to abaxial tepal in Persoonia hakeiformis). Ovary shortly stipitate; ovules 1-7. Fruit a drupe; endocarp stony, penetrating between the seeds. Seeds 1-2, ovoid, not winged.

Drupaceous fruits are likely to be a synapomorphy for this tribe (Weston 1994).

3. Toronia L.A.S.Johnson \& B.G.Briggs

One sp. (T. toru (A.Cunn.) L.A.S.Johnson \& B.G.Briggs), North Island, New Zealand (Allan 1961: 299, as Persoonia toru A.Cunn.).

4. Garnieria Brongn. \& Gris

One sp. (G. spathulifolia (Brongn. \& Gris) Brongn. \& Gris), New Caledonia (Virot 1968: 74-78).

5. Acidonia L.A.S.Johnson \& B.G.Briggs

One sp. (A. microcarpa (R.Br.) L.A.S.Johnson \& B.G.Briggs), SW Australia (Weston 1995a: 49-50).

\section{Persoonia Sm.}

100 spp., widespread in Australia, including Tasmania (Weston 1994, 1995a: 50-125, Weston \& Johnson 1997, Weston 1999).

Persoonia appears to be polyphyletic, with Toronia, Garnieria and Acidonia nested amongst its basal subclades (P.H. Weston and C. Porter, unpublished analysis).

3. Subfamily Symphionematoideae P.H.Weston \& N.P.Barker subfam. nov.

Fasciculi radicum absentes. Cotyledones non auriculatae. Inflorescentiae bracteatae, spicatae sed in Symphionema saepe complexae. Filamenta staminalia basaliter tepalis adnata. Glandes hypogynae absentes. Ovula 1-2. Fructus indehiscens, siccus, tribus alis vel non alatus. Chromosomatum numerus haploideus 10 vel 14 . Genus typicum: Symphionema R.Br.

Cluster roots absent. Cotyledons not auriculate. Inflorescence bracteate, spicate but often compound in Symphionema. Staminal filaments basally adnate to tepals. Hypogynous glands absent. Ovules 1-2. Fruit indehiscent, dry. Chromosomes $n=10$ or 14 , mean length $3.1 \mu \mathrm{m}$.

7. Agastachys R.Br.

One sp. (A. odorata R.Br.), Tasmania (Telford 1995a).

8. Symphionema R.Br.

Two spp., SE Australia (Telford 1995b). 


\section{Subfamily Proteoideae Eaton}

(Eaton 1836: 30)

Synonym: subfamily Eidotheoideae A.W.Douglas \& B.Hyland (Douglas \& Hyland 1995: 472)

Cluster roots present. Cotyledons not auriculate. Inflorescence bracteate, basically racemose but often compound and often condensed to form spikes or capitula, sometimes with different orders of branching differing qualitatively in structure (conflorescences of Johnson \& Briggs 1975). Staminal filaments very slightly to completely adnate to tepals. Ovule 1 ( 2 in a few flowers of some species of Petrophile and Isopogon). Fruit indehiscent. Chromosomes $\mathrm{n}=10-14$, mean length 1.2-3.4 $\mu \mathrm{m}$.

\section{Genera incertae sedis}

9. Eidothea A.W.Douglas \& B.Hyland

Two spp., E Australia (Douglas \& Hyland 1995, Weston \& Kooyman 2002).

10. Beauprea Brongn. \& Gris

13 spp., New Caledonia (Virot 1968: 20-74, 247-250).

\section{Beaupreopsis Virot}

One sp. (B. paniculata (Brongn. \& Gris) Virot), New Caledonia (Virot 1968: 14-19).

12. Dilobeia Thou.

Two spp., E Madagascar (Bosser \& Rabevohitra 1991: 49-58).

13. Cenarrhenes Labill.

One sp. (C. nitida Labill.), Tasmania (Telford 1995c).

14. Franklandia R.Br.

Two spp., SW Australia (George 1995a).

\subsection{Tribe Conospermeae Endl.}

(Endlicher 1837: 338)

Synonym: tribe Stirlingieae Baill. (Baillon 1870: 405, 427)

Involucral bracts absent. Floral bracts inconspicuous, not imbricate, scale-like, not thickening or hardening during fruit development. Flowers sessile. Perianth actinomorphic or zygomorphic. Tepals basally to almost wholly connate. Anther loculi coherent with fertile loculi of adjacent anthers. Hypogynous glands absent. Style tip not functioning as pollen presenter.

4.1.1 Subtribe Stirlingiinae L.A.S.Johnson \& B.G.Briggs

(Johnson \& Briggs 1975: 171)

Plants andromonoecious. Perianth actinomorphic. Anthers all bilocular, fertile.

17. Stirlingia Endl.

Seven spp., SW Australia (George 1995b).

4.1.2 Subtribe Conosperminae L.A.S.Johnson \& B.G.Briggs

(Johnson \& Briggs 1975: 171)

Plants bisexual. Perianth zygomorphic or rarely actinomorphic (some species of Conospermum). Lateral anthers unilocular; adaxial or abaxial stamen sterile.

18. Conospermum Sm.

53 spp., S Australia including Tasmania (Bennett 1995).

19. Synaphea R.Br.

50 spp., SW Australia (George 1995c).

4.2 Tribe Petrophileae P.H.Weston \& N.P.Barker trib. nov.

Inflorescentia involucro bractearum subtenta (Petrophile) vel involucro bractearum et inflorescentiarum sterilifactarum complanatarum subtenta (Aulax). Bracteae 
indurescentes per maturationem fructus (praeter Aulax pallasia), persistentes post liberatio fructuum. Tepala basaliter connata (sed in floris masculinis Aulacis libera). Antherae liberae. Glandes hypogynae absentes. Genus typicum: Petrophile R.Br. ex Knight.

Inflorescence subtended by an involucre of bracts (Petrophile) or an involucre of bracts and sterilised, flattened inflorescences (Aulax). Floral bracts hardening during fruit development (except in Aulax pallasia), persistent until after fruit fall. Tepals basally connate (free in the male flowers of Aulax). Anthers free. Hypogynous glands absent.

15. Petrophile R.Br. ex Knight

53 spp., S Australia (Foreman 1995a).

16. Aulax Berg.

Three spp., Cape region of South Africa (Rourke 1987).

\subsection{Tribe Proteeae}

Floral bracts persistent until after fruit fall. Flowers sessile. Perianth zygomorphic, splitting into two lobes, the anterior tepal free or basally connate to the others, the 3 posterior tepals completely connate or almost so. Anthers free. Style tip functioning as pollen presenter.

20. Protea L.

114 spp. (according to Rourke 1980 and Beard 1992) or 103 spp. (according to Rourke 1980 and Brummitt \& Marner 1993: 8-30), widespread in sub-Saharan Africa.

21. Faurea Harvey

About 15 spp., widespread in sub-Saharan Africa and Madagascar (Brummitt \& Marner 1993: 2-8, Bosser \& Rabevohitra 1991: 58-63).

4.4 Tribe Leucadendreae P.H.Weston \& N.P.Barker trib. nov.

Bracteae involucrales praesentes (absentes in speciebus aliquis Leucadendri, Vexatorellae). Flores sessiles. Tepala basaliter connata (libera in speciebus aliquis Diastellae). Antherae liberae. Apex styli plerumque palynophorio fungens. Genus typicum: Leucadendron R.Br.

Involucral bracts present (absent in some species of Leucadendron, Vexatorella). Flowers sessile. Tepals basally connate (free in some species of Diastella). Anthers free. Style tip functioning as pollen presenter (not so in a few species of Leucadendron).

4.4.1 Subtribe Isopogoninae P.H. Weston \& N.P.Barker subtrib. nov.

Inflorescentia multiflora; bracteae florales caducae ubi fructus liberati. Glandes hypogynae absens. Ovulum orthotropum. Genus typicum: Isopogon R.Br. ex Knight.

Inflorescence multiflowered; floral bracts caducous when fruits are released. Hypogynous glands absent. Ovule orthotropous.

22. Isopogon R.Br. ex Knight

35 spp., S Australia (Foreman 1995b).

4.4.2 Subtribe Adenanthinae L.A.S.Johnson \& B.G.Briggs

(Johnson \& Briggs 1975: 171)

Inflorescences one-flowered; floral bract persistent. Hypogynous glands 4, basally adnate to perianth. Ovule hemitropous.

23. Adenanthos Labill.

33 spp., S Australia (Nelson 1978). 
4.4.3 Subtribe Leucadendrinae P.H.Weston \& N.P.Barker subtrib. nov. Inflorescentia plerumque multiflora (uniflora in speciebus aliquis Spatallae); bracteae florales persistentes. Glandes hypogynae 4, liberae, vel absens (speciebus aliquis Leucadendri et Diastellae). Ovulum hemitropum. Genus typicum: Leucadendron R.Br.

Inflorescence usually multiflowered (one-flowered in some species of Spatalla); floral bracts persistent. Hypogynous glands 4, free, or absent (some species of Leucadendron and Diastella). Ovule hemitropous.

24. Leucadendron R.Br.

80 spp., Cape region, South Africa (Williams 1972).

25. Serruria Salisb.

51 spp., SW Cape region of South Africa (Rebelo 1995).

26. Paranomus Salisb.

18 (+1 excluded by Levyns) spp., Cape region of South Africa (Levyns 1970, Rebelo 1995).

27. Vexatorella Rourke

Four spp., SW Cape region of South Africa (Rourke 1984a).

28. Sorocephalus R.Br.

11 spp., SW Cape region of South Africa (Rourke 1969).

29. Spatalla Salisb.

20 spp., SW Cape region of South Africa (Rourke 1969).

30. Leucospermum R.Br.

48 spp., Cape region of South Africa, NE to the Chimanimani Mountains, Zimbabwe (Rourke 1972).

31. Mimetes Salisb.

13 spp., Cape region of South Africa (Rourke 1984b). Mimetes appears to be polyphyletic, including both Diastella and Orothamnus as subclades (Barker et al. 2002).

32. Diastella Salisb.

Seven spp., SW Cape region of South Africa (Rourke 1976).

33. Orothamnus Pappe ex Hook.

One sp. (O. zeyheri), Cape region of South Africa (Rebelo 1995).

Subfamily Grevilleoideae Engl.

(Engler 1888: 128)

Synonym: subfamily Carnarvonioideae L.A.S.Johnson \& B.G.Briggs (Johnson \& Briggs 1975: 172)

Synonym: subfamily Sphalmioideae L.A.S.Johnson \& B.G.Briggs (Johnson \& Briggs 1975: 172)

Cluster roots present. Cotyledons auriculate or rarely peltate (auricles obscure in a few genera due to thickening or widening of the cotyledons). Inflorescence bracteate, a raceme of flower pairs or a panicle of such racemes (grevilleoid conflorescences of Johnson \& Briggs 1975) (occasionally a simple raceme or panicle of racemes or a highly reduced grevilleoid conflorescence). Staminal filaments basally to completely adnate to tepals.. Fruit not winged. Chromosomes $\mathrm{n}=10-14$, mean length 1.0-2.6 $\mu \mathrm{m}$.

\section{Genera incertae sedis}

34. Sphalmium B.G.Briggs, B.Hyland \& L.A.S.Johnson

One sp. (S. racemosum (C.T.White) B.G.Briggs, B.Hyland \& L.A.S.Johnson), NE Australia (Briggs et al. 1975).

35. Carnarvonia F.Muell.

One sp. (C. araliifolia F.Muell.) with two subspp., NE Australia (Hyland 1995a). 
5.1 Tribe Roupaleae Meisn.

(Meisner 1841: Tab. Diagn. 332, Comm. 245, as Rhopaleae)

Synonym: tribe Oriteae Venkata Rao ex L.A.S.Johnson \& B.G.Briggs (Johnson \& Briggs 1975: 172)

Synonym: tribe Knightieae L.A.S.Johnson \& B.G.Briggs (Johnson \& Briggs 1975: 172)

Synonym: tribe Helicieae L.A.S.Johnson \& B.G.Briggs (Johnson \& Briggs 1975: 173)

Anthers apiculate (inapiculate in Neorites and some species of Orites). Pollen grains triporate. Ovary sessile; style tip functioning as pollen presenter (not so in Neorites and some species of Orites); stigma terminal to subterminal (oblique in Neorites).

Genera incertae sedis

36. Megahertzia A.S.George \& B.Hyland

One sp. (M. amplexicaulis A.S.George \& B.Hyland), NE Australia (George \& Hyland 1995).

37. Knightia R.Br.

One sp. (K. excelsa R.Br.), New Zealand (Allan 1961: 299-300).

38. Eucarpha (R.Br.) Spach

Two spp., New Caledonia (Virot 1968: 236-246, as Knightia).

39. Triunia L.A.S.Johnson \& B.G.Briggs

Four spp., E Australia (Foreman 1995c).

5.1.1 Subtribe Roupalinae L.A.S.Johnson \& B.G.Briggs

(Johnson \& Briggs 1975: 174)

Adult leaves spiral. Ovules orthotropous to hemitropous. Fruit a leathery follicle; seeds winged.

40. Roupala Aubl.

33 spp., widespread in tropical South and Central America (Sleumer 1954: 141-175 but see Prance \& Plana, 1998 and Prance et al., in press, regarding the number of species).

41. Neorites L.S.Sm.

One sp. (N. kevediana L.S.Sm.), NE Australia (Hewson 1995).

42. Orites R.Br.

Eight spp., E Australia including Tasmania, Chile (Sleumer 1954: 140-141, George 1995d).

5.1.2 Subtribe Lambertiinae (C.VenkataRao) L.A.S.Johnson \& B.G.Briggs

(Venkata Rao 1968: 23; Johnson \& Briggs 1975: 174)

Adult leaves opposite-decussate or whorled. Ovules 2, orthotropous to hemitropous.

Fruit a woody follicle; seeds winged.

43. Lambertia Sm.

10 spp., SW and SE Australia (Hnatiuk 1995a).

44. Xylomelum Sm.

Six spp., SW and E Australia (Foreman 1995d).

5.1.3 Subtribe Heliciinae L.A.S.Johnson \& B.G.Briggs

(Johnson \& Briggs 1975: 173)

Synonym: subtribe Hollandaeinae L.A.S.Johnson \& B.G.Briggs (Johnson \& Briggs 1975: 173)

Adult leaves spiral (rarely opposite in Helicia). Ovules anatropous. Seeds not winged.

45. Helicia Lour.

About 100 spp., S India, Sri Lanka, China and Japan to SE Australia, with centre of diversity in New Guinea (Sleumer 1955a: 164-190, Foreman 1995e, 1995i: 234-268, Pham 1992: 86-109, Chung 2002: 170-189). 
46. Hollandaea F.Muell.

Two spp., NE Australia (Hyland 1995b).

5.1.4. Subtribe Floydiinae L.A.S.Johnson \& B.G.Briggs

(Johnson \& Briggs 1975: 174)

Adult leaves spiral. Ovules orthotropous to hemitropous.

47. Darlingia F.Muell.

Two spp., NE Australia (Hyland 1995c).

48. Floydia L.A.S.Johnson \& B.G.Briggs

One sp. (F. praealta (F.Muell.) L.A.S.Johnson \& B.G.Briggs), E Australia (Foreman 1995f).

5.2 Tribe Banksieae Reichb.

(Reichenbach 1828: 82)

Floral bracts present (absent in a few species of Dryandra). Flowers sessile (shortly pedicellate in Austromuellera). Anthers apiculate. Pollen grains biporate. Ovary sessile; style tip functioning as pollen presenter; stigma terminal, oblique or abaxial; ovules 2, hemitropous (anatropous in some species of Banksia and Dryandra). Fruit follicular; seeds winged.

\subsubsection{Subtribe Musgraveinae L.A.S.Johnson \& B.G.Briggs}

(Johnson \& Briggs 1975: 174)

Common peduncle of flower pairs present. Tepals not connate. Hypogynous glands 3. False dissepiment scarcely formed between seeds.

49. Musgravea F.Muell.

Two spp., rainforest, NE Australia (Hyland 1999a).

50. Austromuellera C.T.White

Two spp., NE Australia (Hyland 1999b).

5.2.2 Subtribe Banksiinae L.A.S.Johnson \& B.G.Briggs

(Johnson \& Briggs 1975: 174)

Common peduncle of flower pairs absent. Tepals basally connate. Hypogynous glands 4. False dissepiment formed between seeds.

51. Banksia L.f.

76 spp., widespread in Australia including Tasmania, one sp. extending to S New Guinea (George 1999a).

Banksia is paraphyletic, including Dryandra as a subclade (Mast \& Givnish 2002).

52. Dryandra R.Br.

93 spp., shrublands, woodlands and sclerophyll forests, SW Australia (George 1999b).

5.3 Tribe Embothrieae Reichb.

(Reichenbach 1828: 82)

Synonym: tribe Grevilleeae Endl. (Endlicher 1837: 340)

Common peduncle of flower pairs absent. Floral bracts absent. Flowers pedicellate (except in a few species of Grevillea) Perianth zygomorphic (except in some species of Grevillea and Hakea). Anthers inapiculate (or minutely apiculate). Pollen grains triporate (biporate in Embothrium). Ovary stipitate (sessile in some species of Grevillea); style tip functioning as pollen presenter, usually swollen; ovules hemitropous. Fruit dry, follicular (rarely dry and indehiscent: a few species of Grevillea or drupaceous, with fleshy outer mesocarp and hard inner mesocarp: Finschia); seeds winged (rarely wingless: Finschia, a few species of Grevillea). 
5.3.1 Subtribe Lomatiinae L.A.S.Johnson \& B.G.Briggs (1975: 173)

Inflorescence a raceme of flower pairs or a panicle of such racemes. Hypogynous glands

3. Carpel orientation diagonal.

53. Lomatia R.Br.

12 spp., E Australia including Tasmania, Chile, Argentina, Peru and Ecuador (Sleumer 1954: 196-200, Wilson et al. 1995).

5.3.2 Subtribe Embothriinae Endl.

(Endlicher 1837: 342)

Inflorescence a raceme of flower pairs. Hypogynous gland solitary, crescentic to horseshoe-shaped. Carpel orientation diagonal..

54. Embothrium J.R.Forst. \& G.Forst.

One sp. (E. coccineum R.Forst. \& G.Forst.), Chile, Argentina (Sleumer 1954: 204-207).

55. Oreocallis $\mathrm{R} . \mathrm{Br}$.

One or two spp., Peru and Ecuador (Sleumer 1954: 200-203, omitting O. wickhamii, O. pinnata and O. brachycarpa).

56. Alloxylon P.H.Weston \& Crisp

Four spp., E Australia, S New Guinea and Aru Is (Weston \& Crisp 1991).

57. Telopea R.Br.

Five spp., SE Australia including Tasmania (Crisp \& Weston 1995).

5.3.3 Subtribe Stenocarpinae L.A.S.Johnson \& B.G.Briggs

(Johnson \& Briggs 1975: 172)

Inflorescence an umbel of flower pairs or a panicle of such umbels (reduced to a solitary flower pair or solitary flower in some species of Strangea). Hypogynous gland solitary, oblong to horse-shoe-shaped (Stenocarpus) or absent (Strangea). Carpel orientation antero-posterior.

58. Stenocarpus R.Br.

21 spp., N \& E Australia, New Guinea, Aru Is., New Caledonia (Virot 1968: 176-236, Foreman 1995g). Stenocarpus is probably paraphyletic, including Strangea as a subclade (Weston, Barker and Downs unpublished analysis).

59. Strangea Meisn.

Three spp., SW \& E Australia (Hnatiuk 1995b).

5.3.4 Subtribe Hakeinae Endl.

Endlicher (1837: 340), as Hakeaeae

Synonym: subtribe Buckinghamiinae L.A.S.Johnson \& B.G.Briggs (Johnson \& Briggs 1975: 173)

Inflorescence a raceme or umbel of flower pairs or a panicle of such racemes or umbels (rarely reduced to a single flower in a few species of Grevillea and Hakea). Hypogynous gland solitary, (rarely absent).

60. Opisthiolepis L.S.Sm.

One sp. (O. heterophylla L.S.Sm.), NE Australia (Foreman 1995h).

61. Buckinghamia F.Muell.

Two spp., NE Australia (Foreman \& Hyland 1995).

62. Hakea Schrad. \& J.C.Wendl.

149 spp., widespread in Australia including Tasmania (Barker et al. 1999).

63. Grevillea R.Br. ex Knight

362 spp., widespread in Australia including Tasmania, New Caledonia, New Guinea and Sulawesi (Olde \& Marriott 1994, 1995a,b, Makinson 2000). Grevillea is probably polyphyletic, including both Hakea and Finschia as subclades. 
64. Finschia Warb.

Three spp., New Guinea with one sp. extending NW to Palau Is. and SE to Vanuatu (Foreman 1995i: 228-232).

\subsection{Tribe Macadamieae C.VenkataRao}

(Venkata Rao 1968: 23)

Anthers apiculate. Pollen grains triporate. Ovary sessile; style tip functioning as pollen presenter); ovules 2 (numerous in Cardwellia), orthotropous (hemitropous in Cardwellia). Seeds wingless (winged in Cardwellia).

\subsubsection{Subtribe Macadamiinae L.A.S.Johnson \& B.G.Briggs}

(Johnson \& Briggs 1975: 174)

Common peduncle absent. Floral bracts absent. Flowers pedicellate. Perianth actinomorphic or slightly zygomorphic. Staminal filaments basally to almost completely adnate to tepals. Hypogynous gland solitary, cylindrical to cup like, irregularly lobed, surrounding base of ovary. Carpel orientation antero-posterior or diagonal (polymorphic from flower to flower). Fruit dry, tardily dehiscent or indehiscent, with radially oriented vascular bundles or bundles of fibres in the outer mesocarp. Seed globose or ellipsoidal.

65. Macadamia F.Muell.

Nine spp., E Australia, Sulawesi (Sleumer 1955a: 194-198, Gross 1995, McDonald \& Ismail 1995). Macadamia appears to be paraphyletic, including both Panopsis and Brabejum as subclades (Weston \& Downs unpublished analysis).

66. Panopsis Salisb.

25 spp., widespread in tropical South and Central America (Sleumer 1954: 176-184, Hernandez \& Enrique 1991, Edwards \& Prance 1993, Prance et al. in press).

67. Brabejum L.

One sp. (B. stellatifolium L.), SW Cape region of South Africa (Rebelo 1995).

5.4.2 Subtribe Malagasiinae P.H. Weston \& N.P.Barker subtrib. nov.

Pedunculus communis praesens. Bracteae florales squamiformes. Flores pedicellati. Perianthium actinomorphum. Filamenta staminalior tepalis praeter apices adnatis. Glandes hypogynae 4, liberae. Cursus carpelli incognitus ; ovula 2, orthotropa. Fructus drupaceus; mesocarpus interior durus, pagina laevis; mesocarpus exterior succulentus, fasciculis vascularibus radialibus et fasciculis fibrarum radialibus absentibus. Semen globosum. Genus typicum: Malagasia L.A.S.Johnson \& B.G.Briggs

Common peduncle present. Floral bracts scale like. Flowers pedicellate. Perianth actinomorphic. Staminal filaments adnate to tepals except at tips. Hypogynous glands 4, free. Carpel orientation unknown. Fruit drupaceous; inner mesocarp hard, with a smooth surface; outer mesocarp succulent, lacking radially oriented vascular bundles or bundles of fibres; Seed globose.

68. Malagasia L.A.S.Johnson \& B.G.Briggs

One sp. (M. alticola (Capuron) L.A.S.Johnson \& B.G.Briggs), Madagascar (Bosser \& Rabevohitra 1991: 64-67).

69. Catalepidia P.H.Weston

One sp. (C. heyana (F.M.Bailey) P.H.Weston), NE Australia (Weston 1995c).

5.4.3 Subtribe Virotiinae P.H.Weston \& N.P.Barker subtrib. nov.

Pedunculus communis praesens. Bracteae florales squamiformes. Flores pedicellati. Perianthium actinomorphum. Filamenta staminales tepaliis adnatis. Glandes hypogynae 4, liberae vel glans hypogyna solitaria, annularis, quadrilobata vel denticulata 
(Virotia). Cursus carpelli incognitus. Fructus drupaceus; mesocarpus interior durus, pagina foveolata ad reticulata; mesocarpus exterior succulentus, fasciculis vascularibus radialibus vel fasciculis fibrarum radialibus. Semen ellipsoideum vel compressumellipsoideum. Genus typicum: Virotia L.A.S.Johnson \& B.G.Briggs

Common peduncle present. Floral bracts scale like. Flowers pedicellate. Perianth actinomorphic. Staminal filaments adnate to tepals. Hypogynous glands 4, free or solitary, annular, 4-lobed or denticulate (Virotia). Carpel orientation unknown. Fruit drupaceous; inner mesocarp hard, with pitted to reticulate surface sculpturing; outer mesocarp succulent, with radially oriented vascular bundles or bundles of fibres; seed ellipsoid or compressed-ellipsoid.

70. Virotia L.A.S.Johnson \& B.G.Briggs

Six spp., New Caledonia (Virot 1968: 109-140, as Macadamia, omitting the treatment of $M$. integrifolia as M. ternifolia auct. non F.Muell.).

71. Athertonia L.A.S.Johnson \& B.G.Briggs

One sp. (A. diversifolia (C.T.White) L.A.S.Johnson \& B.G.Briggs), NE Australia (Weston 1995d).

72. Heliciopsis Sleumer

Fourteen spp., Burma and SE China to Malesia, west of Wallace's Line (Sleumer 1955b: 79-86, Kochummen 1973, Pham 1992: 109-112, Kochummen 1973, Chung 2002: 189201).

5.4.4 Subtribe Gevuininae L.A.S.Johnson \& B.G.Briggs

(Johnson \& Briggs 1975: 173)

Synonym: subtribe Cardwelliinae L.A.S.Johnson \& B.G.Briggs (Johnson \& Briggs 1975: 172)

Synonym: subtribe Hicksbeachiinae L.A.S.Johnson \& B.G.Briggs (Johnson \& Briggs 1975: 173)

Common peduncle present or absent. Floral bracts absent. Flowers pedicellate or sessile. Perianth zygomorphic (actinomorphic in Hicksbeachia). Staminal filaments adnate to tepals. Hypogynous glands 4, free (Cardwellia, Sleumerodendron, Hicksbeachia, some species of Euplassa) or 2, anterior, free (Gevuina, Bleasdalea papuana), or solitary, annular and 4-lobed (some species of Euplassa) or solitary, anterior, crescentic to bilobed-oblong (Kermadecia, Turrillia, Bleasdalea bleasdalei). Fruit drupaceous with a hard inner mesocarp with smooth surface and succulent outer mesocarp usually with radially oriented vascular bundles or bundles of fibres (or dry, follicular: Cardwellia); seed globose to ellipsoid or compressed-ellipsoid, not winged (flat, winged, elliptical in Cardwellia).

73. Cardwellia F.Muell.

One sp. (C. sublimis F.Muell.), NE Australia (Hyland 1995d).

74. Sleumerodendron Virot

One sp. (S. austrocaledonicum (Brongn. \& Gris) Virot), New Caledonia (Virot 1968: 101-109).

75. Euplassa Salisb.

20 spp., widespread in tropical South America (Sleumer 1954: 185-196, Plana \& Prance 1998, Prance et al. in press).

76. Gevuina Molina

One sp. (G. avellana Molina), Chile and Argentina (Sleumer 1954: 184-185, Prance et al. in press). 
77. Bleasdalea F.Muell.

Two spp., NE Australia and New Guinea (Foreman 1995i: 225-228, Weston 1995e, as Gevuina).

Recent floristic treatments have placed these two Australasian species in a variety of genera, including Turrillia (Smith 1985) and Gevuina (Weston 1995). On the basis of morphology they seem to be closely related sister species. So far it has not been possible to obtain DNA of B. papuana but molecular systematic analyses (Weston, Barker and Downs unpublished) of B. bleasdalei do not strongly resolve its relationships to other genera of Gevuininae, other than to include it in a clade that excludes Cardwellia.

78. Hicksbeachia F.Muell.

Two spp., E Australia (Weston 1988).

79. Kermadecia Brongn. \& Gris

Four spp., New Caledonia (Virot 1968: 78-101).

Weston and Crisp (1996) asserted, on the basis of floral morphology, that K. pronyensis is misplaced in Kermadecia. However, molecular systematic analyses (Weston, Barker and Downs unpublished) strongly group it with other species of Kermadecia.

80. Turrillia A.C.Sm.

Three spp., Vanuatu, Fiji (Smith \& Haas 1975 as Bleasdalea, but omitting B. papuana and B. bleasdalei).

Recent taxonomic and floristic treatments have placed these three species in a variety of genera, including Bleasdalea (Smith \& Haas 1975). On the basis of morphology they seem to form a clade of closely related species. So far it has been possible to obtain DNA of only T. lutea from Vanuatu and molecular systematic analyses (Weston, Barker and Downs unpublished) weakly group it with Kermadecia.

\section{Acknowledgments}

We are grateful to the following people for kindly helping us at various stages in this project. Katherine Downs assisted in the production of ITS nrDNA sequence data that contributed to one of our input trees, which will be published elsewhere. Karen Wilson checked our botanical Latin. She and Dr Peter Wilson advised us on nomenclatural matters. Dr Barbara Briggs and Dr Peter Stevens provided helpful comments on an earlier draft of the manuscript. This paper is dedicated to Barbara Briggs and the late Dr Lawrie Johnson, who both encouraged us to test and improve their classification.

\section{References}

Allan HH (1961) Flora of New Zealand, vol. 1. (Government Printer: Wellington)

Backlund A \& Bremer K (1998) To be or not to be - principles of classification and monotypic plant families. Taxon 47: 391-400.

Baillon HE (1870) Histoire des plantes. Monographie des Protéacées. (L. Hachette et Cie: Paris)

Barker NP, Weston PH, Rourke JP \& Reeves G (2002) The relationships of the southern African Proteaceae as elucidated by internal transcribed spacer (ITS) DNA sequence data. Kew Bulletin 57: 867-883.

Barker W, Haegi L \& Barker R (1999) Hakea. Pp. 1-170 in Wilson A (ed.) Flora of Australia, vol. 17B. (CSIRO Publishing: Melbourne)

Beard JS (1992) The proteas of tropical Africa. (Kangaroo Press: Kenthurst)

Bennett EM (1995) Conospermum. Pp. 224-271 in McCarthy P (ed.) Flora of Australia, vol. 16. (CSIRO Australia: Melbourne) 
Bieleski RL \& Briggs BG (2005) Taxonomic patterns in the distribution of polyols within the Proteaceae. Australian Journal of Botany 53: 205-217.

Bininda-Emonds ORP (2003) Novel versus unsupported clades: assessing the qualtitative support for clades in MRP supertrees. Systematic Biology 52: 839-848.

Bininda-Emonds ORP (2004) The evolution of supertrees. Trends in Ecology and Evolution 19: $315-322$.

Bininda-Emonds ORP, Gittleman JL \& Steel MA (2002) The (super)tree of life: procedures, problems, and prospects. Annual Review of Ecology and Systematics 33: 265-289.

Briggs BG, Hyland BPM \& Johnson LAS (1975) Sphalmium, a distinctive new genus of Proteaceae from North Queensland. Australian Journal of Botany 23: 165-172.

Bosser J \& Rabevohitra R (1991) Protéacées. Pp. 47-69 in Morat P (ed.) Flore de Madagascar et des Comores, Familles 45, 57, 93, 94, 107. (Muséum National d'Histoire Naturelle: Paris)

Brummitt RK (1996) In defence of paraphyletic taxa. Pp. 371-384 in van der Maesen, LJG, van der Burgt XM \& van Medenbach de Rooy JM (eds) The biodiversity of African plants. (Kluwer: Dordrecht)

Brummitt RK \& Marner SK (1993) Proteaceae. Pp. 1-30 in Polhill RM (ed.) Flora of Tropical East Africa. (A.A. Balkema: Rotterdam)

Carpenter RJ, Hill RS \& Jordan GJ (2005) Leaf cuticular morphology links Platanaceae and Proteaceae. International Journal of Plant Sciences 166: 843-855.

Catling DM \& Gates PJ (1995) Leaf anatomy in Hakea Schrader (Proteaceae). Botanische Jahrbucher fur Systematik Pflanzengeschichte und Pflanzengeographie 117: 153-172.

Chung RCK (2002) Proteaceae. Pp. 169-201 in Soepadmo E, Saw LG \& Chung RCK (eds) Tree flora of Sabah and Sarawak, vol. 4. (Forest Research Institute Malaysia: Selangor Darul Ehsan)

Collins BG \& Rebelo T (1987) Pollination biology of the Proteaceae in Australia and southern Africa. Australian Journal of Ecology 12: 387-422.

Crisp MD \& Weston PH (1995) Telopea. Pp. 386-390 in McCarthy P (ed.) Flora of Australia, vol. 16. (CSIRO Australia: Melbourne)

Douglas AW \& Hyland BPM (1995) Subfamily Eidotheoideae. Pp. 127-129, 472-473 in McCarthy P (ed.) Flora of Australia, vol. 16. (CSIRO Australia: Melbourne)

Dettmann ME \& Jarzen DM (1998) The early history of the Proteaceae in Australia: the pollen record. Australian Systematic Botany 11: 401-438.

Douglas AW (1995) Affinities. Pp. 6-14 in McCarthy P (ed.) Flora of Australia, vol. 16. (CSIRO Australia: Melbourne)

Douglas AW (1996) Inflorescence and floral development of Carnarvonia (Proteaceae). Telopea 6: 749-774.

Douglas AW \& Tucker SC (1996a) Inflorescence ontogeny and floral organogenesis in Grevilleoideae (Proteaceae), with emphasis on the nature of the flower pairs. International Journal of Plant Sciences 157: 341-372.

Douglas AW \& Tucker SC (1996b) The developmental basis of diverse carpel orientations in Grevilleoideae (Proteaceae). International Journal of Plant Sciences 157: 373-397.

Eaton A (1836) Eaton's botanical grammar and dictionary, modernised down to 1836 (Oliver Steele: Albany)

Edwards KS \& Prance GT (1993) New species of Panopsis (Proteaceae) from South America. Kew Bulletin 48: 637-662.

Endlicher SL (1837) Genera Plantarum, part 5. (Fr. Beck: Vienna)

Engler A (1888) Die Natürlichen Pflanzenfamilien, Teil III, vol. 2, fascicle 29. (Wilhelm Engelmann: Leipzig)

Entwisle TJ \& Weston PH (2005) Majority rules, when systematists disagree. Australian Systematic Botany 18: 1-6.

Feuer S (1990) Pollen morphology of the Embothrieae (Proteaceae) II. Embothriinae (Embothrium, Oreocallis, Telopea). Grana 29: 19-36. 
Foreman DB (1995a) Petrophile. Pp. 149-193 in McCarthy P (ed.) Flora of Australia, vol. 16. (CSIRO Australia: Melbourne)

Foreman DB (1995b) Isopogon. Pp. 194-223 in McCarthy P (ed.) Flora of Australia, vol. 16. (CSIRO Australia: Melbourne)

Foreman DB (1995c) Triunia. Pp. 404-407 in McCarthy P (ed.) Flora of Australia, vol. 16. (CSIRO Australia: Melbourne)

Foreman DB (1995d) Xylomelum. Pp. 399-403 in McCarthy P (ed.) Flora of Australia, vol. 16. (CSIRO Australia: Melbourne)

Foreman DB (1995e) Helicia. Pp. 393-399 in McCarthy P (ed.) Flora of Australia, vol. 16. (CSIRO Australia: Melbourne)

Foreman DB (1995f) Floydia. Pp. 417-419 in McCarthy P (ed.) Flora of Australia, vol. 16. (CSIRO Australia: Melbourne)

Foreman DB (1995g) Stenocarpus. Pp. 363-369 in McCarthy P (ed.) Flora of Australia, vol. 16. (CSIRO Australia: Melbourne)

Foreman DB (1995h) Opisthiolepis. Pp. 373-374 in McCarthy P (ed.) Flora of Australia, vol. 16. (CSIRO Australia: Melbourne)

Foreman DB (1995i) Proteaceae. Pp. 221-270 in Conn BJ (ed.) Handbooks of the flora of Papua New Guinea, vol. 3. (Melbourne University Press: Melbourne)

Foreman DB \& Hyland BPM (1995) Buckinghamia. Pp. 371-373 in McCarthy P (ed.) Flora of Australia, vol. 16. (CSIRO Australia: Melbourne)

George AS (1995a) Franklandia. Pp. 316-317 in McCarthy P (ed.) Flora of Australia, vol. 16. (CSIRO Australia: Melbourne)

George AS (1995b) Stirlingia. Pp. 136-140 in McCarthy P (ed.) Flora of Australia, vol. 16. (CSIRO Australia: Melbourne)

George AS (1995c) Synaphea. Pp. 271-315 in McCarthy P (ed.) Flora of Australia, vol. 16. (CSIRO Australia: Melbourne)

George AS (1995d) Orites. Pp. 346-352 in McCarthy P (ed.) Flora of Australia, vol. 16. (CSIRO Australia: Melbourne)

George AS (1999a) Banksia. Pp. 175-251 in Wilson A (ed.) Flora of Australia, vol. 17B. (CSIRO Publishing: Melbourne)

George AS (1999b) Dryandra. Pp. 251-363 in Wilson A (ed.) Flora of Australia, vol. 17B. (CSIRO Publishing: Melbourne)

George AS \& Hyland BPM (1995) Megahertzia. Pp. 355, 497-498 in McCarthy P (ed.) Flora of Australia, vol. 16. (CSIRO Australia: Melbourne)

Goloboff PA (2005) Minority rule supertrees? MRP, compatability and minimum flip may display the least frequent groups. Cladistics 21: 282-294.

Gross CL (1995) Macadamia. Pp. 419-425 in McCarthy P (ed.) Flora of Australia, vol. 16. (CSIRO Australia: Melbourne)

Hennig W (1966) Phylogenetic systematics. (Illinois University Press: Urbana)

Hernandez G \& Enrique L (1991) Revision de las especies Colombianas del genero Panopsis (Proteaceae). Caldasia 16: 459-484.

Hewson HJ (1995) Neorites. Pp. 352-353 in McCarthy P (ed.) Flora of Australia, vol. 16. (CSIRO Australia: Melbourne)

Hill RS, Scriven LJ \& Jordan GJ (1995) The fossil record of Australian Proteaceae. Pp. 21-30 in McCarthy P (ed.) Flora of Australia, vol. 16. (CSIRO Australia: Melbourne)

Hnatiuk RJ (1995a) Lambertia. Pp. 425-436 in McCarthy P (ed.) Flora of Australia, vol. 16. (CSIRO Australia: Melbourne)

Hnatiuk RJ (1995b) Strangea. Pp. 360-363 in McCarthy P (ed.) Flora of Australia, vol. 16. (CSIRO Australia: Melbourne)

Hoot SB \& Douglas AW (1998) Phylogeny of the Proteaceae based on atp $\beta$ and atp $\beta-r b c L$ intergenic spacer region sequences. Australian Systematic Botany 11:301-320.

Hyland BPM (1995a) Carnarvonia. Pp. 343-345 in McCarthy P (ed.) Flora of Australia, vol. 16. (CSIRO Australia: Melbourne) 
Hyland BPM (1995b) Hollandaea. Pp. 391-393 in McCarthy P (ed.) Flora of Australia, vol. 16. (CSIRO Australia: Melbourne)

Hyland BPM (1995c) Darlingia. Pp. 356-357 in McCarthy P (ed.) Flora of Australia, vol. 16. (CSIRO Australia: Melbourne)

Hyland BPM (1995d) Cardwellia. Pp. 358-359 in McCarthy P (ed.) Flora of Australia, vol. 16. (CSIRO Australia: Melbourne)

Hyland BPM (1999a) Musgravea. Pp. 170-172 in Wilson A (ed.) Flora of Australia, vol. 17B. (CSIRO Publishing: Melbourne)

Hyland BPM (1999b) Austromuellera. Pp. 173-175 in Wilson A (ed.) Flora of Australia, vol. 17B. (CSIRO Publishing: Melbourne)

Johnson LAS and Briggs BG (1975) On the Proteaceae - the evolution and classification of a southern family. Botanical Journal of the Linnean Society 70: 83-182.

Jussieu AL (1789) Genera plantarum. (Vidnam Herissant: Paris)

Kochummen KM (1973) Notes on the systematy of Malayan Phanerogams XXII. Heliciopsis (Proteaceae). The Gardens' Bulletin Singapore 26: 286-287.

Lee HM (1978) Studies of the family Proteaceae II. Further observations on the root morphology of some Australian genera. Proceedings of the Royal Society of Victoria 90: 251-256.

Levyns MR (1970) A revision of the genus Paranomus (Proteaceae). Contributions from the Bolus Herbarium 2: 3-48.

McDonald JA \& Ismail R (1995) Macadamia erecta (Proteaceae), a new species from Sulawesi. Harvard Papers in Botany 7: 7-10.

Makinson RO (2000) Grevillea. Pp. 1-460 in Wilson AJG (ed.) Flora of Australia, vol. 17B. (CSIRO Publishing: Melbourne)

Mast AR (1998) Molecular systematics of the subtribe Banksiinae (Banksia and Dryandra; Proteaceae), based on cpDNA and nrDNA sequence data: implications for taxonomy and biogeography. Australian Systematic Botany 11:321-342.

Mast AR \& Givnish TJ (2002) Historical biogeography and the origin of stomatal distributions in Banksia and Dryandra (Proteaceae) based on their cpDNA phylogeny. American Journal of Botany 89: 1311-1323.

Meisner CF (1841) Plantarum vascularium genera, Fasc. 10. (Libraria Weidmannia: Leipzig)

Midgley JJ (1987) The derivation, utility and implications of a divergence index for the fynbos genus Leucadendron (Proteaceae). Botanical Journal of the Linnean Society 95: 137-152.

Nelson EC (1978) A taxonomic revision of the genus Adenanthos (Proteaceae). Brunonia 1: 303-406.

Nelson G \& Platnick N (1981) Systematics and biogeography: cladistics and vicariance. (Columbia University Press: New York)

Nicolson SW \& Van Wyk B-E (1998) Nectar sugars in Proteaceae: patterns and process. Australian Journal of Botany 46: 489-504.

Olde P \& Marriott N (1994) The Grevillea Book, vol. 1. (Kangaroo Press: Kenthurst)

Olde P \& Marriott N (1995a) The Grevillea Book, vol. 2. (Kangaroo Press: Kenthurst)

Olde P \& Marriott N (1995b) The Grevillea Book, vol. 3. (Kangaroo Press: Kenthurst)

Pham HH (1992) Proteaceae. Pp. 82-114 in Morat P (ed.) Flore du Cambodge du Laos et du Vietnam, vol. 26. (Muséum National d'Histoire Naturelle: Paris)

Plana V \& Prance GT (1998) A new species of Euplassa (Proteaceae) from Brazil. Kew Bulletin 53: 967-971.

Prance GT \& Plana V (1998) The American Proteaceae. Australian Systematic Botany 11: 287299.

Prance GT, Plana V, Edwards KS \& Pennington RT (in press) Proteaceae. Flora Neotropica.

Rebelo AG (1995) SASOL proteas: a field guide to the proteas of southern Africa (Fernwood Press: Vlaeberg)

Reichenbach HG (1828) Conspectus regni vegetabilis. (Carolum Cnobloch: Leipzig)

Rourke JP (1969) Taxonomic studies on Sorocephalus R.Br. and Spatalla Salisb. Journal of South African Botany, Supplementary Volume 7: 1-124. 
Rourke JP (1972) Taxonomic studies of Leucospermum R.Br. Journal of South African Botany, Supplementary Volume 8: 1-194.

Rourke JP (1976) A revision of Diastella (Proteaceae). Journal of South African Botany 42: 185210.

Rourke JP (1980) The proteas of southern Africa. (Purnell: Cape Town)

Rourke JP (1984a) Vexatorella Rourke, a new genus of the Proteaceae from southern Africa. Journal of South African Botany 50: 373-391.

Rourke JP (1984b) A revision of Mimetes Salisb. (Proteaceae). Journal of South African Botany 50: 171-236.

Rourke JP (1987) The inflorescence morphology and systematics of Aulax (Proteaceae). South African Journal of Botany 53: 464-480.

Sankowsky G, Sankowsky N, Radke P \& Radke A (1988) A field guide to the rainforest Proteaceae of North Queensland, 2nd edition. (published by the authors: Tolga \& Walkamin)

Sleumer H (1954) Proteaceae americanae. Botanischer Jahrbucher 76: 139-211.

Sleumer H (1955a) Proteaceae. Flora Malesiana (series 1) 5: 147-206.

Sleumer H (1955b) Studies in Old World Proteaceae. Blumea 8: 1-95.

Smith AC (1985) Flora Vitiensis nova: a new flora of Fiji (spermatophytes only). (Pacific Tropical Botanical Garden: Lawai)

Smith AC \& Haas JE (1975) Studies of Pacific island plants XXIX. Bleasdalea and related genera of Proteaceae. American Journal of Botany 62: 133-147.

Stace HM, Douglas AW \& Sampson JF (1998) Did 'paleo-polyploidy' really occur in Proteaceae? Australian Systematic Botany 11: 613-629.

Stroeschen B (1986) Contributions to the biology of useful plants 6. Anatomical studies of fruit development and fruit classification of Persoonia pinifolia R.Br. Angewandte Botanik 60: 257-265.

Telford IRH (1995a) Agastachys. P. 131 in McCarthy P (ed.) Flora of Australia, vol. 16. (CSIRO Australia: Melbourne)

Telford IRH (1995b) Symphionema. Pp. 133-135 in McCarthy P (ed.) Flora of Australia, vol. 16. (CSIRO Australia: Melbourne)

Telford IRH (1995c) Cenarrhenes. Pp. 131-133 in McCarthy P (ed.) Flora of Australia, vol. 16. (CSIRO Australia: Melbourne)

Thiele K \& Ladiges PY (1996) A cladistic analysis of Banksia (Proteaceae). Australian Systematic Botany 9: 661-733.

Venkata Rao C (1968) Studies in the Proteaceae XI. Morphology, floral anatomy and embryology of Lambertia Sm. with a discussion on the taxonomic position of the genus. Proceedings of the Indian Academy of Science. 48B: 11-24.

Venkata Rao C (1971) Proteaceae. (Council of Scientific \& Industrial Research: New Delhi)

Virot R (1968) Protéacées. Pp. 5-254 in Aubreville A (ed.) Flore de la Nouvelle Calédonie et Dépendances, vol. 2. (Muséum National d'Histoire Naturelle: Paris)

Weston PH (1988) A revision of Hicksbeachia (Proteaceae). Telopea 3: 231-239.

Weston PH (1994) The Western Australian species of subtribe Persooniinae

(Proteaceae: Persoonioideae: Persoonieae). Telopea 6: 51-165.

Weston PH (1995a) Persoonioideae. Pp. 47-124, 471-472 in McCarthy P (ed.) Flora of Australia, vol. 16. (CSIRO Australia: Melbourne)

Weston PH (1995b) Bellendenoideae. Pp. 125-127, 472 in McCarthy P (ed.) Flora of Australia, vol. 16. (CSIRO Australia: Melbourne)

Weston PH (1995c) Catalepidia. Pp. 415-416, 499 in McCarthy P (ed.) Flora of Australia, vol. 16. (CSIRO Australia: Melbourne)

Weston PH (1995d) Athertonia. Pp. 413-415 in McCarthy P (ed.) Flora of Australia, vol. 16. (CSIRO Australia: Melbourne)

Weston PH (1995e) Gevuina. Pp. 408-410 in McCarthy P (ed.) Flora of Australia, vol. 16. (CSIRO Australia: Melbourne) 
Weston PH \& Johnson LAS (1997) Persoonia hindii (Proteaceae), a new species from the Newnes Plateau, New South Wales. Telopea 7: 199-203.

Weston PH (1999) Persoonia pauciflora (Proteaceae), a new species from the Hunter Valley, New South Wales. Telopea 8: 159-164.

Weston PH \& Crisp MD (1991) Alloxylon (Proteaceae), a new genus from New Guinea and eastern Australia. Telopea 4: 497-507.

Weston PH \& Crisp MD (1994) Cladistic biogeography of Waratahs and their allies (Embothrieae: Proteaceae) across the Pacific. Australian Systematic Botany 7: 225-249.

Weston PH \& Crisp MD (1996) Trans-Pacific biogeographic patterns in the Proteaceae. Pp. 215232 in: Keast A \& Miller SE (eds) The origin and evolution of Pacific island biotas, New Guinea to eastern Polynesia: patterns and processes (SPB Academic Publishing: Amsterdam)

Weston PH \& Kooyman RM (2002) Systematics of Eidothea (Proteaceae), with the description of a new species, E. hardeniana, from the Nightcap Range, north-eastern New South Wales. Telopea 9: 821-832.

White CT \& Francis WD (1924) Contributions to the Queensland Flora. No. 2. Proceedings of the Royal Society of Queensland 35: 63-84.

Williams I (1972) A revision of the genus Leucadendron (Proteaceae). Contributions from the Bolus Herbarium 3: 1-425.

Wilson AJG, Hewson HJ \& Mowatt J (1995) Lomatia. Pp. 374-382 in McCarthy P (ed.) Flora of Australia, vol. 16. (CSIRO Australia: Melbourne)

Wiltshire RJE \& Stace HM (1997) The cytotaxonomy of four Tasmanian genera of Proteaceae. Telopea 7: 181-185.

Manuscript received 03 March 2006, accepted 21 August 2006 